\title{
The Brazilian entomologist Messias Carrera (1907-1994): Biobibliographical profile
}

\author{
Luiz Gustavo Vargas Salgado ${ }^{1}$; Alcimar do Lago Carvalho ${ }^{2}$ \& Carlos José Einicker Lamas ${ }^{3}$ \\ 1 Colégio Pedro II, Departamento de Biologia e Ciências. Rio de Janeiro, RJ, Brasil. \\ ORCID: http://orcid.org/0000-0001-6044-9801. E-mail: salgadolgv@cp2.g12.br \\ ${ }^{2}$ Universidade Federal do Rio de Janeiro (UFRJ), Museu Nacional, Departamento de Entomologia. Rio de Janeiro, RJ, Brasil. \\ ORCID: http://orcid.org/0000-0002-5588-788X. E-mail: alagoc@acd.ufrj.br \\ ${ }^{3}$ Universidade de São Paulo (USP), Museu de Zoologia (MZUSP). São Paulo, SP, Brasil. \\ ORCID: http://orcid.org/0000-0002-7750-590X. E-mail: einicker@usp.br
}

\begin{abstract}
The present article focuses on the life trajectory and the bibliographic production of the entomologist and science communicator Messias Carrera (1907-1994), presenting aspects of his personal profile, academic training and professional development. His role as a researcher in the Zoology Department of Secretaria de Agricultura, Indústria e Comércio do Estado de São Paulo, currently Museu de Zoologia of the Universidade de São Paulo, is emphasized, having worked mainly in the taxonomy of insects of the order Diptera and in science communication between the 1930s and 1990s. Carrera was a science researcher and communicator ahead of his time. His intellectual production, limited to the scientific, technological and "humanistic" spheres, adds important advances to the relative areas of knowledge.
\end{abstract}

Keywords. Messias Carrera; Biography; Bibliography; Diptera; Taxonomic list; Science communication.

\begin{abstract}
Resumo. 0 entomólogo brasileiro Messias Carrera (1907-1994): Perfil Biobibliográfico. 0 presente artigo tem como foco a trajetória de vida e a produção bibliográfica do entomólogo e divulgador da ciência Messias Carrera (1907-1994), sendo apresentados aspectos de seu perfil pessoal, de sua formação acadêmica e de seu desenvolvimento profissional. 0 seu papel como pesquisador do Departamento de Zoologia da Secretaria de Agricultura, Indústria e Comércio do Estado de São Paulo, atual Museu de Zoologia da Universidade de São Paulo, é enfatizado, tendo atuado principalmente na taxonomia dos insetos da ordem Diptera e na divulgação científica entre as décadas de 1930 e 1990. Carrera foi um pesquisador e divulgador de ciência a frente do seu tempo. Sua produção intelectual, circunscrita às esferas científica, tecnológica e "humanística", acrescenta avanços importantes para as relativas áreas do conhecimento.
\end{abstract}

Palavras-Chave. Messias Carrera; Biografia; Bibliografia; Diptera; Lista taxonômica; Divulgação científica.

\section{INTRODUCTION}

Messias Carrera (1907-1994) was an important Brazilian entomologist who, during the decades of 1930 to 1990 , worked with the taxonomy of insects of the order Diptera and with science communication (Fig. 1). For 27 years (1935-1962), he was professionally linked to the Zoology Department of Secretaria de Agricultura, Indústria e Comércio do Estado de São Paulo, currently Museu de Zoologia of the Universidade de São Paulo (MZUSP), São Paulo, having started there as an unpaid intern and retired as Chief Biologist of the Insecta Division (Nomura, 1958, 1995a, b; Carrera, 1991b). His intellectual production is very significant in all areas where he worked. In the taxonomy of the order Diptera, more especially of the families Asilidae and Syrphidae, he proposed several new taxa, even describing 36 in a single title (Carrera, 1949a). In science communication, his production was even more expressive, having been published in several media, such as widely circulated newspapers and magazines, and awarded the Prêmio José Reis de Divulgação Científica e Tecnológica (award for science and technological communication) in 1987 (CNPq, 2010). Certainly, many of his texts served as starting points for several studies, some of which are well known by most Brazilian biologists, such as the book Entomologia para você (Entomology for you) (Fig. 2), where he makes it clear that: "Awakening a vocation is the author's most vehement desire" (Carrera, 1973, p. 11). 


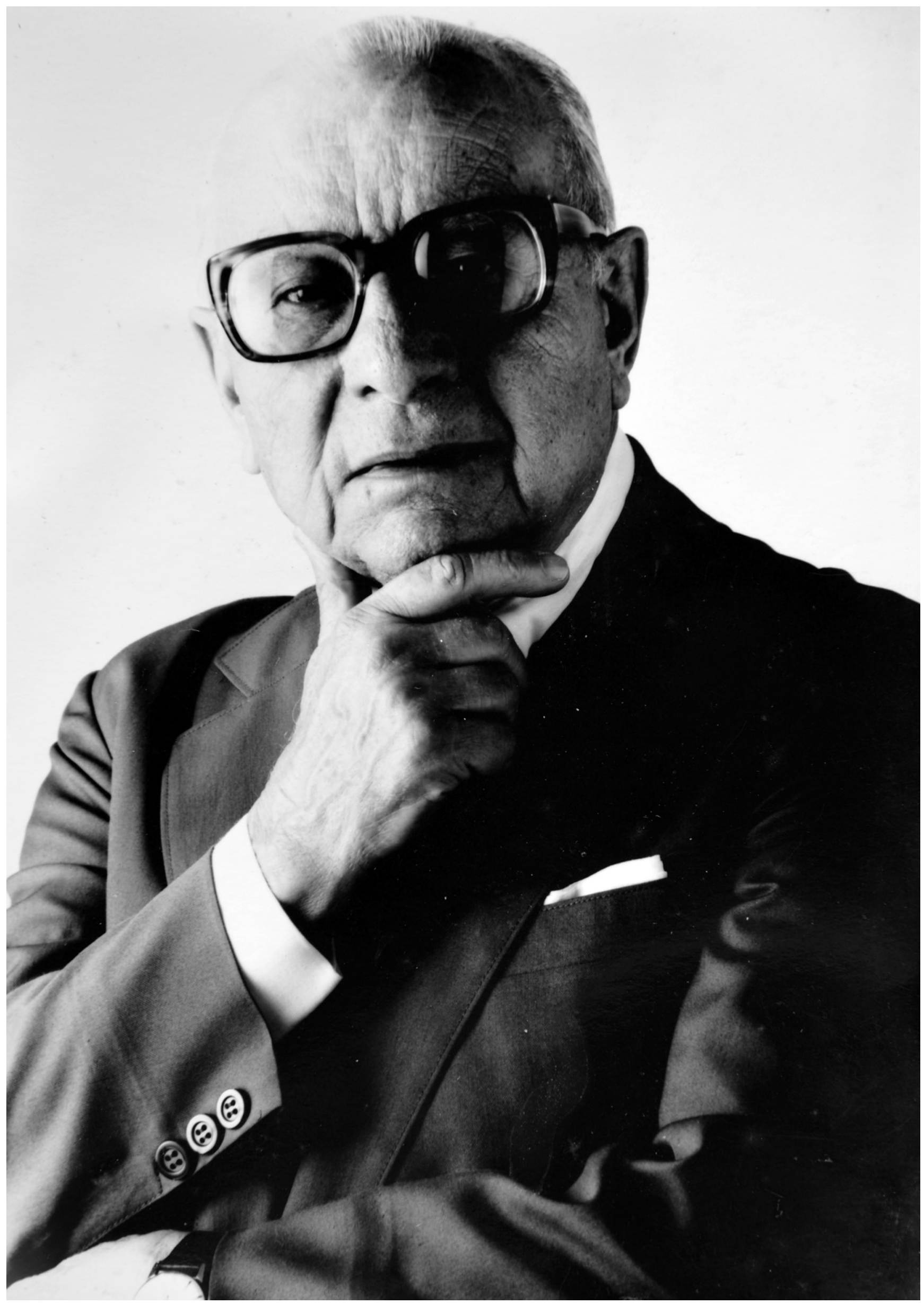

Figure 1. Messias Carrera (1907-1994). Photo taken during the 1990s. Provided by his family members. 
The structuring of the biography of a renowned researcher like Messias Carrera and gathering an important part of the history of Entomology and science communication in Brazil is also relevant for providing elements for deepening and reflecting on the development of his fields of activity. His life and work have already been the focus of some concise titles, such as a necrology (Nomura, 1995a) and a biography (Nomura, 1995b), both written by fellow zoologist and friend Prof. Dr. Hitoshi Nomura (1933-2017) (Crozariol, 2017). This article presents a more extensive biobibliographical analysis that adds new data in addition to ratifying and rectifying previously disclosed information. Thus, this biographical study has a critical focus, making it possible to highlight the author's personal and professional convictions and characteristics, allowing a more contextualized look at his life story. The bibliographic inventory carried out was not restricted to the list of published titles, presenting a critical assessment of the production as a whole. Thus, it was possible to contextualize them in the historical scope of Entomology, science communication, and education, and ponder their relevance.

\section{MATERIAL AND METHODS}

The biobibliographic data related to Messias Carrera, referred to only as Carrera henceforth in this text, were gathered through the analysis of the following sources: original titles of his work; biography and obituary published by Hitoshi Nomura (Nomura, 1995a, b); functional documents filed at the Museu de Zoologia of the Universidade de São Paulo (MZUSP); interviews with family members, employees at Universidade de São Paulo (USP), and other researchers who had contact with the studied author. Also, nominal records were searched in the electronic databases of the following sources: newspaper Folha de S. Paulo; Hemeroteca Digital, Biblioteca Nacional; Diário Oficial da União; Diário Oficial do Estado de São Paulo.

The survey of Carrera's biobibliographic information was started by examining the publications that already exist in the literature that address his life and work, the obituary published in the Revista Brasileira de Entomologia (Nomura, 1995a) and the author's biography published in the book Vultos da Zoologia Brasileira, Volume VI (Nomura, 1995b). The focus of these sources is on his academic and professional life, and a list of genera and species names that honor him is also presented. The obituary presents a list of scientific articles published by the author, but which is incomplete.

In Carrera's three books, Entomologia para você (Carrera, 1973), Insetos de interesse médico e veterinário (Insects of medical and veterinary interest) (Carrera, 1991a) (Fig. 3) and Insetos, lendas e história (Insects, legends, and history) (Carrera, 1991b) (Fig. 4), there is some direct information or evidence of his professional profile and personal life that were compiled and organized in this article. These are scattered mainly in their introductory sections, such as prefaces and introductions, written by the author or by important professionals in their fields, such as Júlio Seabra Inglez de Souza
(1915-1998), an agronomist of great importance for Viticulture and Brazilian enology (Agricultura, 1998), José Reis (1907-2002), "dean" of scientific journalism in Brazil (Giacheti, 2006), and Prof. Dr. Nelson Papavero, renowned Brazilian entomologist (Klassa \& Santos, 2014).

In the personnel and expedient section of the MZUSP, a folder with functional Carrera documents is filed. The following were found: record with functional history, curriculum vitae, health and physical capacity certificate, attendance certificates, calculations of the length of service, nominations, removal requests (collection, collection analysis, and lectures/classes), collection reports, and other documents related to his professional life (e.g., Fig. 5). After the analysis of such material, it was possible to gather information about his career as a biologist at the institution in question.

Were also used as a research sources: collections of the newspaper Folha de S. Paulo (http://acervo.folha. com.br), journals present in the Hemeroteca Digital da Biblioteca Nacional (http://bndigital.bn.br/hemeroteca-digital), Diário Oficial da União, and the Diário Oficial do Estado de São Paulo (http://www.jusbrasil.com.br). In these, searches were made for the terms 'Messias Cassanha Carrera', 'Messias Cassaña Carrera', 'Messias Carrera,',Messias', and 'Carrera'. The information found refers both to the author's personal and professional life. These databases were accessed throughout the research development, between 2014 and 2017, with August 30, 2017 being the date of the last access.

The interviews were conducted through electronic mail or in person, some of which were recorded in audio and video. All were conducted based on a standardized questionnaire, consisting of about twenty open questions. In some cases, this was adapted to the interviewee's professional profile or relationship level with Carrera. The general objective of the interviews was to raise the interviewees' impressions about the author in focus so that, with the help of the sources previously presented, more reliable information could be obtained or checked. The questions were organized according to their objectives in five blocks, namely: the interviewee's relationship with Carrera; Carrera's professional profile; Carrera's role in Brazilian Entomology/Dipterology; Carrera's role in Brazilian scientific dissemination; Carrera's personal/psychological profile.

The interviewed ones were: Cleide Costa (retired), Eliana Marques Cancello and Nelson Papavero (retired), Ph.D. professors from MZUSP; Prof. Dr. Sergio Antonio Vanin (1948-2020, then retired), from the Zoology Department, Instituto de Biociências, Universidade de São Paulo (USP); Prof. Dr. Hitoshi Nomura (then retired), from the Escola Superior de Agricultura Luiz de Queiroz, USP; Dr. Carlos Eduardo Machado-Allison, from Academia Nacional de Ciencias Físicas, Matemáticas y Naturales de Venezuela, Caracas (retired); in addition to the employees of MZUSP Mrs. Dione Seripierri, chief librarian, and Mr. Carlos Campaner, a technician at the Entomology Service. Carrera's family members interviewed were his daughter, Mrs. Helena Carrera Chiavassa, and his son-inlaw, Mr. Sérgio Chiavassa. 
To contextualize the information presented here in relation to researchers and public persons cited in the text, their names can be followed by two types of data: dates of birth and death, only when the person is deceased; quotes from biographies or obituaries, when available in the literature. These are presented only af-

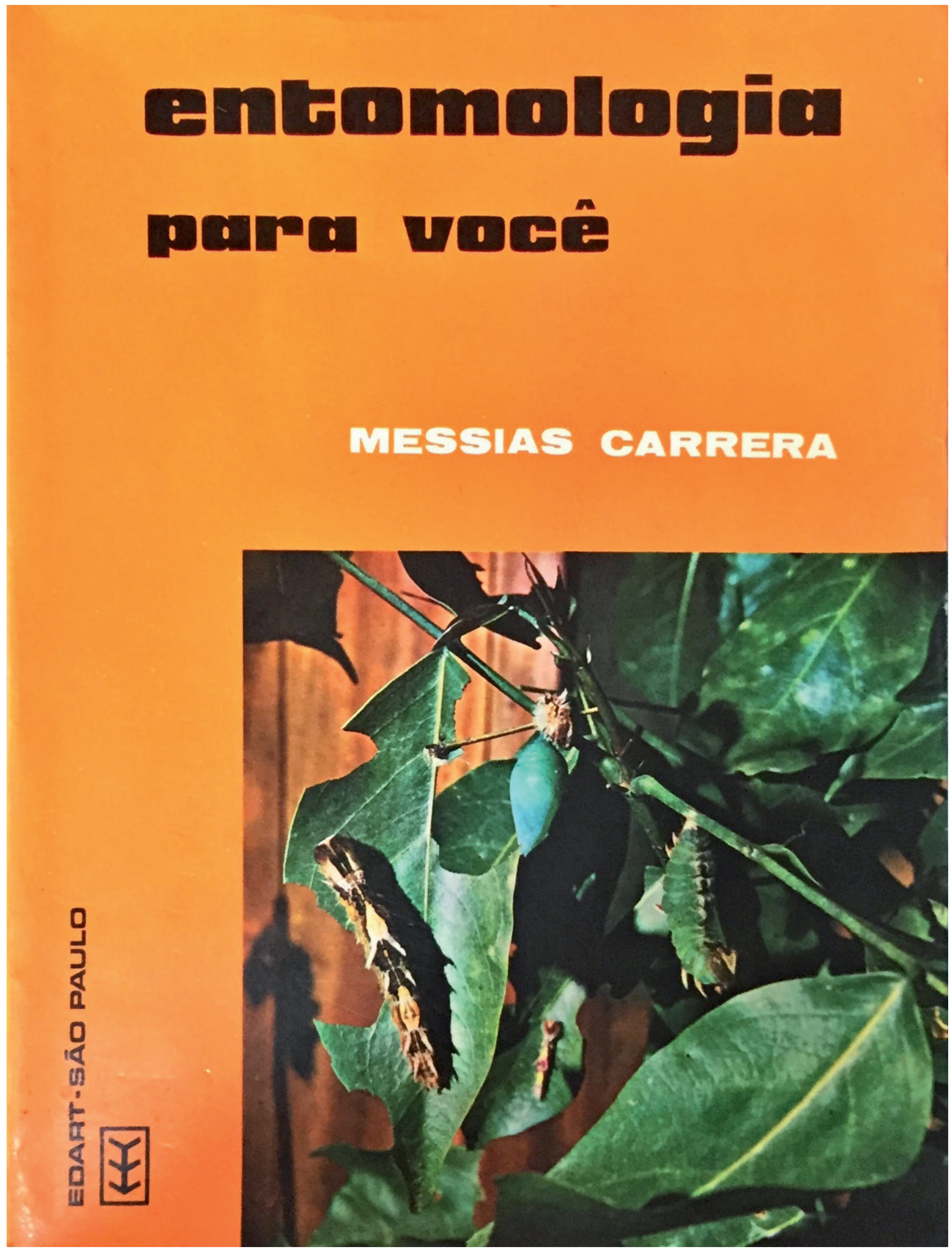

Figure 2. Cover of the fourth edition of the book Entomologia para você, published in 1973 by EDART, São Paulo. 
ter the first mention of the given name. The information presented in this article expresses the authors' point of view from the direct interpretation of the collected data, thus assuming responsibility for omissions, misinterpretations, or errors.

\section{Biographical study}

This section was divided into three subsections to group related information and facilitate the data presentation. The first, entitled "Personal profile", presents

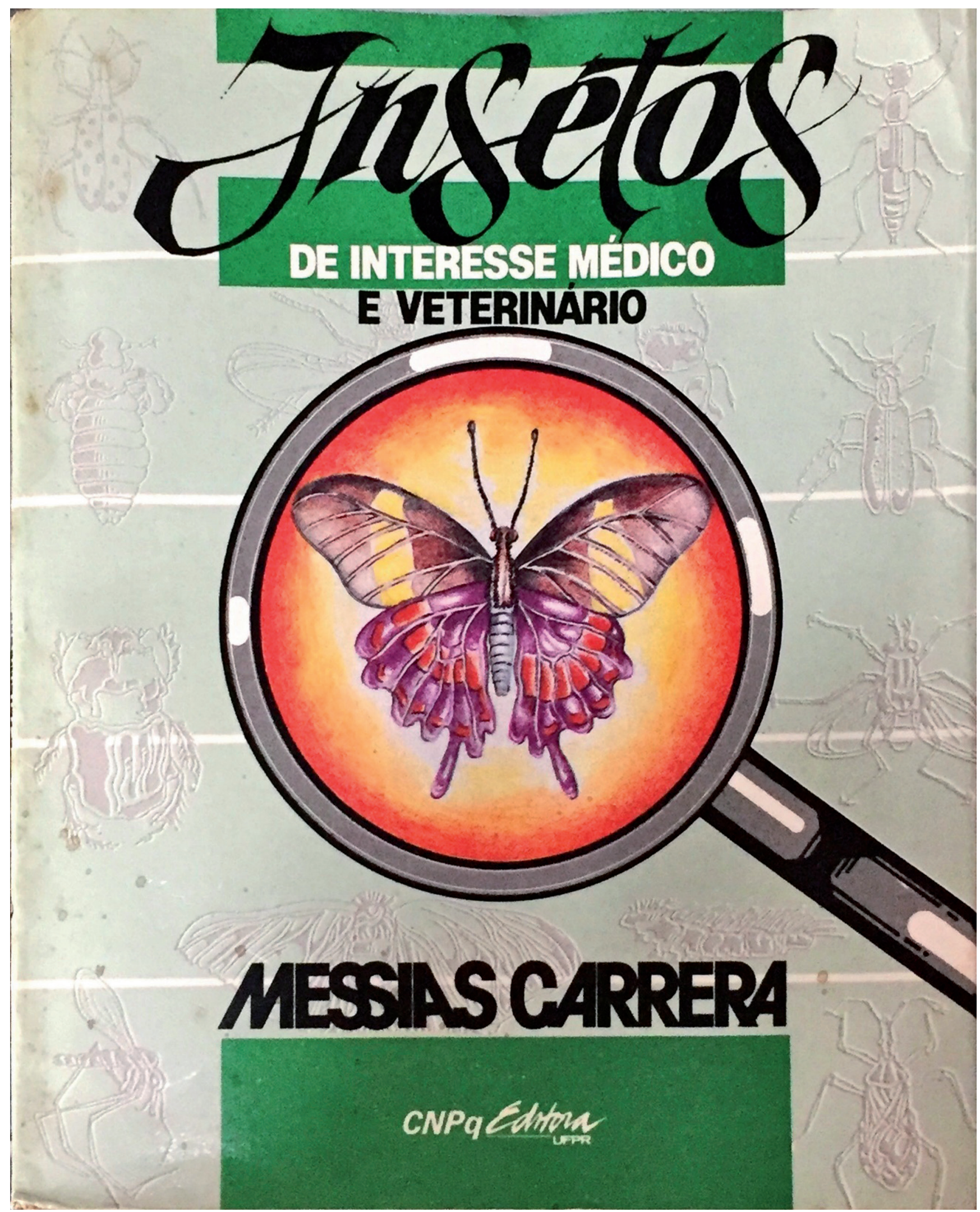

Figure 3. Cover of the book Insetos de interesse medico e veterinário, published in 1991 by Editora da UFPR, Curitiba. 
facts of Carrera's personal life, highlighting his personal convictions and characteristics, based mainly on a critical appreciation of the interviews carried out. The subse- quent two, entitled "Basic studies and academic training" and "Academic and professional development," critically present his academic and professional life events.

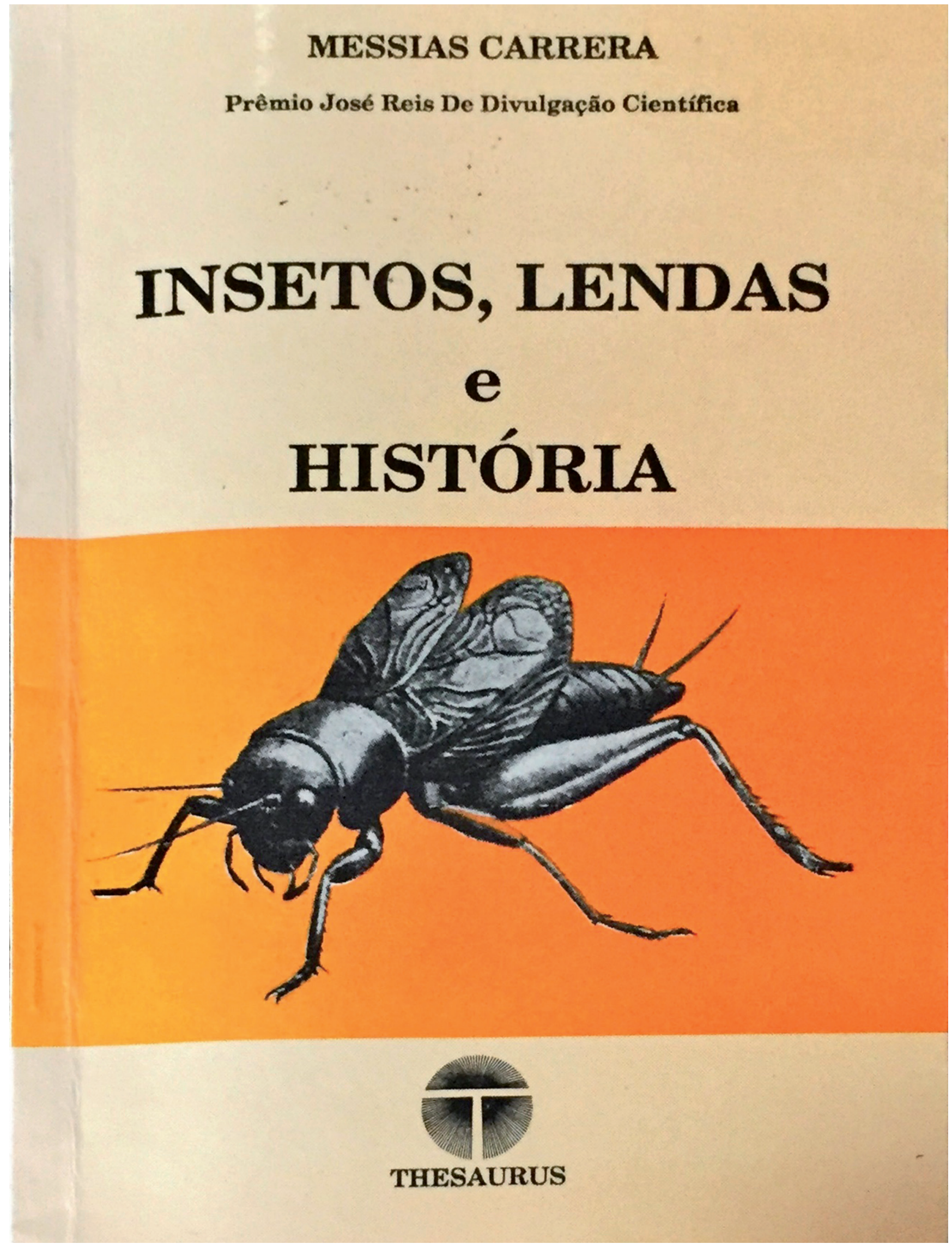

Figure 4. Cover of the book Insetos, lendas e história published in 1991 by Editora Thesaurus, Brasília. 


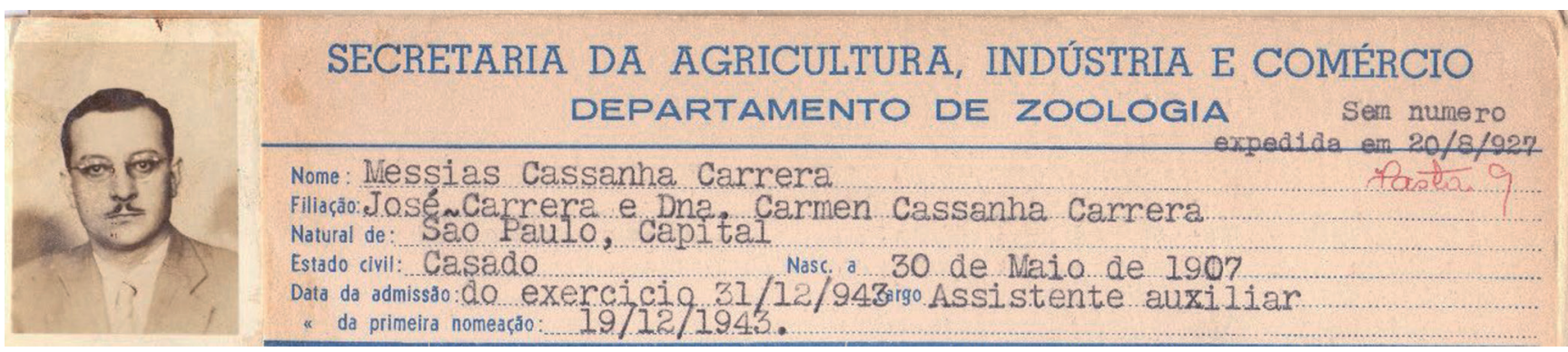

Figure 5. Header of the Messias Carrera frequency card in the Zoology Departament of Secretaria de Agricultura, Indústria e Comércio de São Paulo, SP.

\section{Personal profile}

Messias Cassaña Carrera, first of the five children of the Spanish Carmen Cassaña Carrera and the Brazilian José Carrera, was born on May 30, 1907, in the city of São Paulo. On June 19, 1937, in the subdistrict Lapa of the same city in which he was born, he married Ivonette Camargo, with whom he had his only daughter named Helena Camargo Carrera, born on November 10, 1938.

According to Mrs. Helena, as a young man, her father lived on a farm in the inland of the state of São Paulo, currently, in the municipality of Várzea Paulista, where his grandfather was head of the local railway station. From an early age, José, Carrera's father, was already interested in insects and liked to collect them, especially butterflies. Nomura (1958) transcribes some words from Carrera that corroborate this information:

"among the memories of my childhood are vivid ones in which I find myself running through the fields after yellow butterflies, to catch them with a coarse and enormous sack of burlap attached to a barrel arch, and the one in which I am surprised, in a vague and imprecise scenario, with a beetle in my hands, admiring its bright colors and the bizarre structure of its antennae" (Nomura, 1958, p. 55).

From this, it can be inferred that having spent childhood in the countryside, thus having more direct contact with nature, was one of the motivating factors that led him to dedicate himself to study insects. Coincidentally, the father of the famous German dipterologist Emil Hans Willi Hennig (1913-1976) was also the head of a railway station in an inland city. Having spent his childhood in such a place was crucial for establishing his psychological profile, admitted the mentioned author (Schmitt, 2010).

"Synésio", as he was called by his relatives, a name his mother would like Carrera to have been registered, was seen as a very good, charitable, and generous person, yet easily irritable and with a very strong personality. Due to his ease in getting out of control, he often starred in comical situations. As an example, his relatives narrate that when participating in family card games, which by the way he did not play very well, he was irritated when losing and ended up crushing or tearing the cards in the deck. Very close to the family, he liked everyone close by, becoming a little possessive, but always to protect. His daughter says that, on one occasion, he refused a proposal to study in the United States of America so as not to have to stay away from his family. Apparently, he did not use to share work matters with his relatives. Only his brother-in-law, Doctor Renato de Robert Corrêa (1908-1987), a former doctor of the former Serviço de Profilaxia da Malária do Estado de São Paulo (Malaria Prophylaxis Service of the State of São Paulo) and first secretary of the Sociedade Brasileira de Entomologia (Brazilian Society of Entomology) from 1951 to 1957 (Carrera, 1987), had some affinity with his area of expertise.

According to Mr. Sérgio Chiavassa, his son-in-law, in general, he did not like changes, having some resistance to technological progress and advancement. He was against the government of Juscelino Kubitschek (1902-1976), Brazilian president between 1956 and 1961 (Couto, 2011) because he represented progress due to his development policy, which promised the growth of "50 years in 5" (Fazenda, 1988). Such resistance ended up influencing his life a lot. This can be seen in the following facts: the decision to obtain a driver's license only at the age of 58, to avoid traveling by plane, and not to being interested in television or films. He had a large collection of books and, in fact, enjoyed spending most of his free time in his library. It is worth highlighting his interest in encyclopedias, such as Mirador Internacional, Delta Larousse, and the famous Encyclopædia Britannica. These were the research sources existing at the time most used and present in most public and school libraries (Campello et al., 1993), and even in homes. Carrera's interest in encyclopedias was so great that he became responsible for some entries at Mirador Internacional, at the time announced as the first genuinely Brazilian encyclopedia (Fonseca, 1972).

Besides his great passion for his professional activity, he developed some hobbies, among which philately stands out, having assembled a beautiful collection of stamps. Concerning sports, he loved watching football matches, being a fan of São Paulo FC, whose headquarters are located in São Paulo. However, in sports practice, he identified more with individual modalities. He trained rowing on the Tietê River, an exercise that today would be unthinkable due to the high level of pollution that this river currently presents (Rocha, 1992). During the 1930s, he trained in fencing at the Clube de Regatas Tietê, becoming champion in the rapier and saber modalities 
(Correio Paulistano, 1934, 1935a). He loved to travel by car, having known almost all the Brazilian states. Because he was afraid of flying, he made only two international trips, one to Europe and the other to the United States of America. When visiting the library of the American Museum of Natural History in New York, he was very happy to find his book Entomologia para você in the institution's collection (verbal information').

His daughter, in her interview, highlighted two important moments in the author's life. The first was his father's involvement in the 1932 Constitutional Revolution, also known as the 1932 Revolution or Paulista War (Donato, 2002). She says he did not shoot, having joined the movement only to upset his parents. The second was his participation in the television show O Céu é o Limite ("The Sky is the Limit") from TV Tupi in São Paulo during the 1950s. In this, the participant chose a topic and answered questions that, when correct, were converted into money. Of course, he chose Entomology as his theme, and he was almost the champion. He was disqualified only on the last question to reach the maximum prize, but, according to his family, unfairly, since there was an error on the part of the program's production, as he proved behind the scenes. He was correct, but the station had removed the question template from an encyclopedia where the information was wrong. Even so, unfortunately, there was no retraction, and he did not receive the prize. This unfortunate episode may have been one of the reasons for the production of five articles by the author that addressed conceptual errors in entomological terminologies found in dictionaries and encyclopedias (Carrera, 1991c, d, 1992, 1993a, b) and a title in the column Histórias de insetos (Stories of insects) (Carrera, 1964).

As called by his co-workers, "Professor Messias" was very dear and respected, having a good personal relationship in his professional environment. Everyone liked to tease him because he took provocations seriously due to his temperament and, consequently, starred in hilarious moments. One of these was described by Prof. Dr. Nelson Papavero in an informal conversation. He said that Dr. Hélio Ferraz de Almeida Camargo (1922-2006), an ornithologist at MZUSP (Höfling, 2006), used to imitate Dr. Olivério Mário de Oliveira Pinto (1896-1981), director of MZUSP in the 1930s (Nomura, 1991a), for whom Carrera was very fond of. Sometimes, Dr. Hélio Camargo knocked on the door of Carrera' office, imitating Dr. Olivério Pinto. When he opened and noticed his colleague's provocation, he was irritated and, at times, "made a gesture with his legs", which, according to Nelson Papavero, was "unique in the world; I don't know where he invented it". With some, friendship went beyond the professional environment. According to his daughter and son-in-law, some even went to his home. Among the names they remembered were researchers Hitoshi Nomura, Lauro Pereira Travassos Filho (1918-1989) (Nomura, 1992), Maria Aparecida Vulcano d'Andretta, Nelson Papavero, Paulo Sawaya (1903-1995) (Kaphan, 2003), and Ubirajara Ribeiro Martins de Souza (1932-2015) (Galileo \& Santos-

1 Information provided by Mrs. Helena Carrera when interviewed.
Silva, 2015). The following are some comments from some of the professionals who had the pleasure of living with him, revealing his personality:

"Messias was a very intelligent and sensitive person. He told me that people have to act half with the brain and half with the heart. The brain alone does not work, nor just the heart. That is, the relationship with people has to be thought [brain] and pondered [heart]. His presence radiated joy, satisfaction, and a guarantee that we had a true teacher around us". Carlos Campaner (Entomology Service of MZUSP), on March 17, 2016.

"[...] He was a very kind person, always in a good mood and a joke teller, attentive eyes, translating a liveliness still present, he thought quickly". Dione Seripierri (Chief librarian at MZUSP), on March 17, 2016.

"He was a very kind person who treated his friends and admirers with respect. Sturdy, of medium height, prescription glasses, he had the pose of a teacher. Besides being passionate about old books on natural history, he loved reading police works, especially those written by Agatha Christie". Hitoshi Nomura (Escola de Agricultura Luiz de Queiroz, USP), on March 18, 2016.

"Prof. Carrera was an extremely simple, kind, and generous person, always in a good mood and affable; but occasionally, when something irritated him, his Spanish blood boiled and changed, but he soon returned to his usual goodness, with a wide smile. He was very emotional and sensitive. He always dressed neatly, in a suit and tie. After his retirement, he often came to the Museu de Zoologia to see his friends". Nelson Papavero (MZUSP), on March 16, 2016.

Several illnesses affected Carrera throughout his life. To treat them, in addition to consulting with his trusted doctors in the city of São Paulo, he took advantage of the healing properties of the baths in the mineral waters of the spa of Águas de Lindóia, São Paulo, a city he used to travel to every year. In the 1970s, he was diagnosed with prostate cancer, which spread to the bones and intestines, a disease that lasted for approximately 13 years and greatly weakened him, both physically and psychologically. However, the health condition that made him more depressed was a vision problem diagnosed as macular degeneration, as it hindered him from reading and writing his articles. Despite his health problems, especially his eyesight, he did not give in easily, having used a magnifying glass for his readings, which continued until late at night. He only stopped reading when the illness really made it completely impossible. 
On December 2, 1994, Brazilian entomology lost one of its great names. At the age of 87 , Carrera dies, having been buried in the cemetery of Araçá, in the neighborhood of Pacaembu, São Paulo. His seventh-day mass took place in the church of São Francisco de Assis, in Vila Clementino, in the same city (verbal information ${ }^{2}$ ).

\section{Basic studies and academic training}

Carrera completed primary school at Grupo Escolar Prudente de Morais, in the city of São Paulo. In January 1930, he took the entrance exam, an assessment necessary to move to the next level of the Brazilian educational system at the time, to Ginásio Paulistano, having completed the first part of the high school in 1934, at the age of 27 (curriculum vitae - functional documents, MZUSP). Greedy for knowledge, he attended the Colégio Universitário in 1937 and 1938 to finish high school and finally enter university.

Having passed the entrance exams at the age of 32 , he enrolled in the natural sciences course at USP's Faculdade de Filosofia, Ciências e Letras in 1939 (Carrera, 1991b). Initially, he studied only the disciplines of Invertebrate Zoology, Vertebrate Zoology, and General and Animal Physiology, taught by Professors Ernest Marcus (1893-1968) (Mendes, 1994) and Paulo Sawaya (1903-2003) (Carrera, 1991b; Nomura, 1995a). In 1941, he received the certification relating only to these disciplines, having returned to the Faculdade de Filosofia, Ciências e Letras in 1955, to enroll in the disciplines Cytology and Plant Morphology. At that time, he met and became friends with the researcher Hitoshi Nomura (Nomura, 1995a). In 1954, at the age of 47 , he received the title of Specialist in Medical Entomology by the Faculdade de Higiene e Saúde Pública of the Universidade de São Paulo.

\section{Professional and academic development}

Carrera entered the job market still during his basic studies in January 1930, at the age of 22, having played the role of Post and Telegraph Agent, a company where he worked for 14 years (Correio Paulistano, 1935b; Carrera, 1991b). Between 1942 and 1950, he was a teacher of Basic Education, more specifically of the $3^{\text {rd }}$ high school year of the scientific course, in private educational institutions in the city of São Paulo, such as Colégio AngloLatino, Colégio Bandeirantes, Colégio Pan-Americano de Medicina, and the Instituto Mackenzie (Folha de S. Paulo, 1944; Carrera, 1991b; Nomura, 1995a, b). At these institutions, he taught the subjects of Natural History and Practical Zoology in pre-polytechnic and pre-medical courses, which were part of the second segment of high school and which, in the 1940s, had the level of specialization (Palma Filho, 2010).

His relationship with the current MZUSP started long before he entered the university. On July 22, 1935,

2 Information provided by Mrs. Helena Carrera when interviewed. at the age of 28 , he began a voluntary internship at the Invertebrate Section at the Museu Paulista. At that moment, his dedication and passion to the study of the order Diptera began (Nomura, 1958, 1995a, b). As for his supervision in this initial period, there are two conflicting pieces of information. According to Carrera (1991a) and Nomura $(1958,1995 a$, b), he was supervised by entomologist John Lane (1905-1963) (Nomura, 1991c), who studied insects of the order Diptera. However, Prof. Dr. Nelson Papavero, who was his intern, when interviewed, made it clear that, in fact, who had been Carrera's supervisor was the entomologist Frederico Lane (1901-1979), specialist of the order Coleoptera (Nomura, 1991b). From 1939, he started to attend the Insecta Division, where he supervised the Diptera Collection of the Zoology Department of Secretaria de Agricultura, Indústria e Comércio do Estado de São Paulo (Secretariat of Agriculture, Industry and Commerce of the State of São Paulo) (curriculum vitae - functional documents, MZUSP). This collection had no responsible specialist until then (Carvalho et al., 2002). According to Nelson Papavero, it was reduced to a single drawer, given to him by Frederico Lane, where there was a mix of dipterans. However, from it, he founded the nucleus of dipterology in the State of São Paulo. He further completes saying:
"And he started off wrong because he saw a cute bug he liked and tried to identify, alone man, it's very difficult. Then he got to Asilidae, so he loved it. Years later, he came back to find out about the genre. It was a Stratiomyidae, a Chiromyza, which is at the base of the "Stratio" [Stratiomydae], but there you go, it is difficult, and Diptera is not easy". (Verbal information ${ }^{3}$ )

On December 15, 1943, at the age of 36, he was admitted to the position of "Assistant" in the Insecta Division at the Zoology Department of the then Museu Paulista. He assumed the position of biologist on May 12, 1945, on a provisional basis, having been hired in the same position, on February 11,1946, the year when he completed 39 years.

On December 29, 1952, Lucas Nogueira Garcez (1913-1982), governor of the State of São Paulo (Mayer \& Garcez, s.d.), enacted Law No. 2,124. This reduced to the position of Assistant those employees who held the position of Biologist who did not have a university degree (Functional history - functional documents, MZUSP). Carrera and other researchers who were in this situation filed a lawsuit to appeal the decision. However, on November 24, 1953, the governor issued an order that once again fits Biologist's position, nominally, the employees previously demoted, among them, Carrera himself (Brasil, 1953, p. 2). This was possibly one of the reasons why, in 1955, he returned to the Faculdade de Filosofia, Ciências e Letras to complete the university course. However, no information was found that the author, in fact, concluded it.

3 Information provided by Prof. Dr. Nelson Papavero when interviewed. 


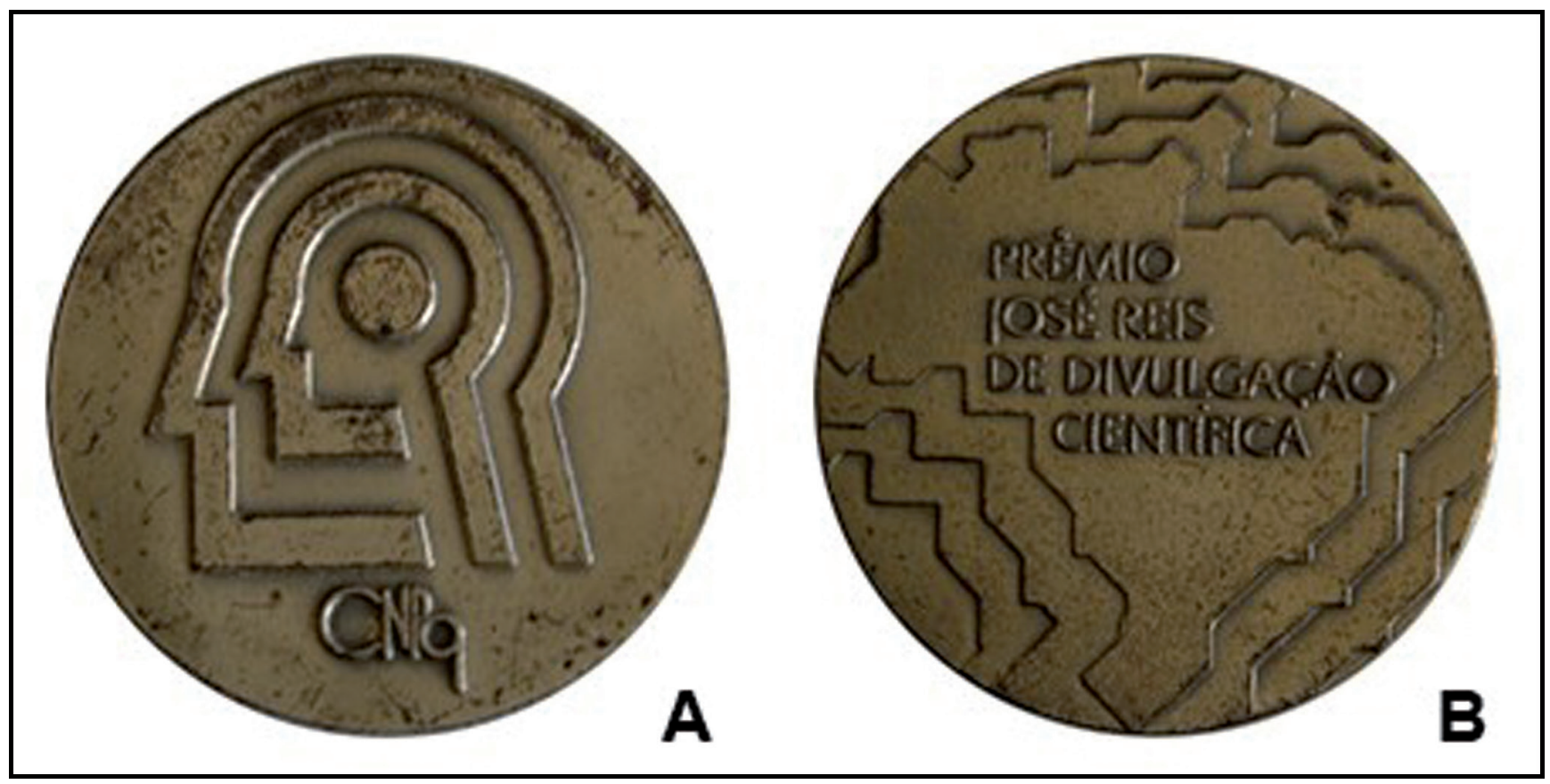

Figure 6. Commemorative medal referring to the VIII Prêmio José Reis de Divulgação Científica received by Messias Carrera in 1988. ( $A=$ front, $B=$ back).

As an effective employee at the Zoology Department of Secretaria de Agricultura, Indústria e Comércio do Estado de São Paulo, he quickly ascended professionally. In July 1946, recently made effective, he received a compliment from the then Secretary of State for Education and Public Health, Dr. Christiano Altenfelder Silva (1889-[?]), one of the founders of USP (Anonymous, 1984), for the efficient and valuable cooperation provided during his term. According to Nomura (1995a) and Carrera (1991a), Carrera became head of the Insecta Division of this department, the current Entomology Service at MZUSP, in 1957. When analyzing his functional records filed at MZUSP, it was clear that this function had already been performed by him when he replaced biologist Carlos Amadeu de Camargo Andrade ([?]-[?]) on December 12, 1953. Over the years of work, he went through several promotions on merit in his career as a biologist, becoming chief biologist on January 18, 1962. According to his daughter, in that same year, he hoped to be appointed director of the institution since he already performed the functions assigned to the position in question. However, herpetologist Paulo Emilio Vanzolini (1924-2013) (Dias, 2013) is the one who was nominated. On the other hand, the closest colleagues claim that Carrera never aspired to take up such a position (verbal information ${ }^{4}$ ). In any case, a few months later, Carrera decides to retire on September 26, 1962, at the age of 55. Nelson Papavero says that when Carrera retires, he leaves the collection with around twenty-five thousand specimens. His position is then occupied, in January 1963, by José Henrique Guimarães (1937-2008), a world-renowned researcher in the study of the Diptera of the Tachinidae family (Lamas et al., 2008).

Even after his retirement, he continued to produce, having, on July 13, 1988, received the Prêmio José Reis

4 Information provided by Prof. Dr. Nelson Papavero after reviewing the first version of this manuscript. de Divulgação Científica e Tecnológica (award for scientific and technological dissemination) (Fig. 6) in reference to 1987 (CNPq, 2010). However, even with the great intention of continuing to publish, he had great difficulty doing so, according to her daughter and Prof. Dr. Cleide Costa, due to advances in his ophthalmic problems.

Throughout his academic life, he participated actively in several scientific societies. Among these, the Sociedad Uruguaya de Entomología (corresponding partner), Sociedade Brasileira de Zoologia (honorary member), Sociedade Paulista da História da Medicina (full member), and, in particular, the Sociedade Brasileira de Entomologia (Fig. 7), and Sociedade Brasileira para o Progresso da Ciência, of which he was a founding member (Carrera, 1991b). Due to this active participation and valuable contribution to Brazilian zoology, he was honored by the Sociedde Brasileira de Zoologia at the XX Congresso Brasileiro de Zoologia (Fig. 8), held in the city of Rio de Janeiro, in July 1994 (Nomura, 1995a).

\section{Bibliographic study}

During his academic life, Carrera published titles in several areas, but with an emphasis on science communication and the order Diptera study. He produced, uninterruptedly, for 55 years, having published his first article on November 15, 1939, in the magazine Chácaras e Quintais. To draw attention and disseminate scientific knowledge to the lay reader, this one was entitled Moscas Assassinas (Robber Flies) (Fig. 9), which alludes to the predatory voracity of the Diptera of the family Asilidae (Diptera). At the same time, it was praised by Amadeu Amadei Barbiellini (1877-1955), editor of the magazine where it was published (Carrera, 1956), for the author's brilliant debut (Carrera, 1939). His last two titles were published on June 30,1995 , six months after his death, in 
the Revista Brasileira de Entomologia. These, also framed as science communication, are entitled Escarabeoideos Fúnebres e Sagrados (Funerary and Sacred Scaraboids) (Carrera, 1995a) and O 'besouro bombardeiro' e seu aparelho detonante (The 'bombardier beetle' and its detonating apparatus) (Carrera, 1995b).

Only three titles are found in the literature presenting surveys of the author's work. The first is present in the inner fold of the back cover of his book Insetos, lendas e história. In this, 292 titles are cited, which are: the book Entomologia para você, 67 scientific articles, 152 articles for science communication, 26 bibliographical reviews, nine entomological entries for encyclopedia Mirador Internacional, ten responses to queries on entomology, ten translations, five biographies and obituaries, seven didactic textbooks, and the remainder of scientific excursion reports, lectures, and reports (Carrera, 1991b). The other two, which are the biography and obituary published by Hitoshi Nomura, share the same information (Nomura, 1995a, b). There are 232 titles listed, of which: 68 scientific articles (only 65 are referenced, however), 91 titles in the Folha de S. Paulo, Histórias de insetos column, three books, four newspaper reports, 24 book reviews, six biographies, seven textbooks for teaching purpos-

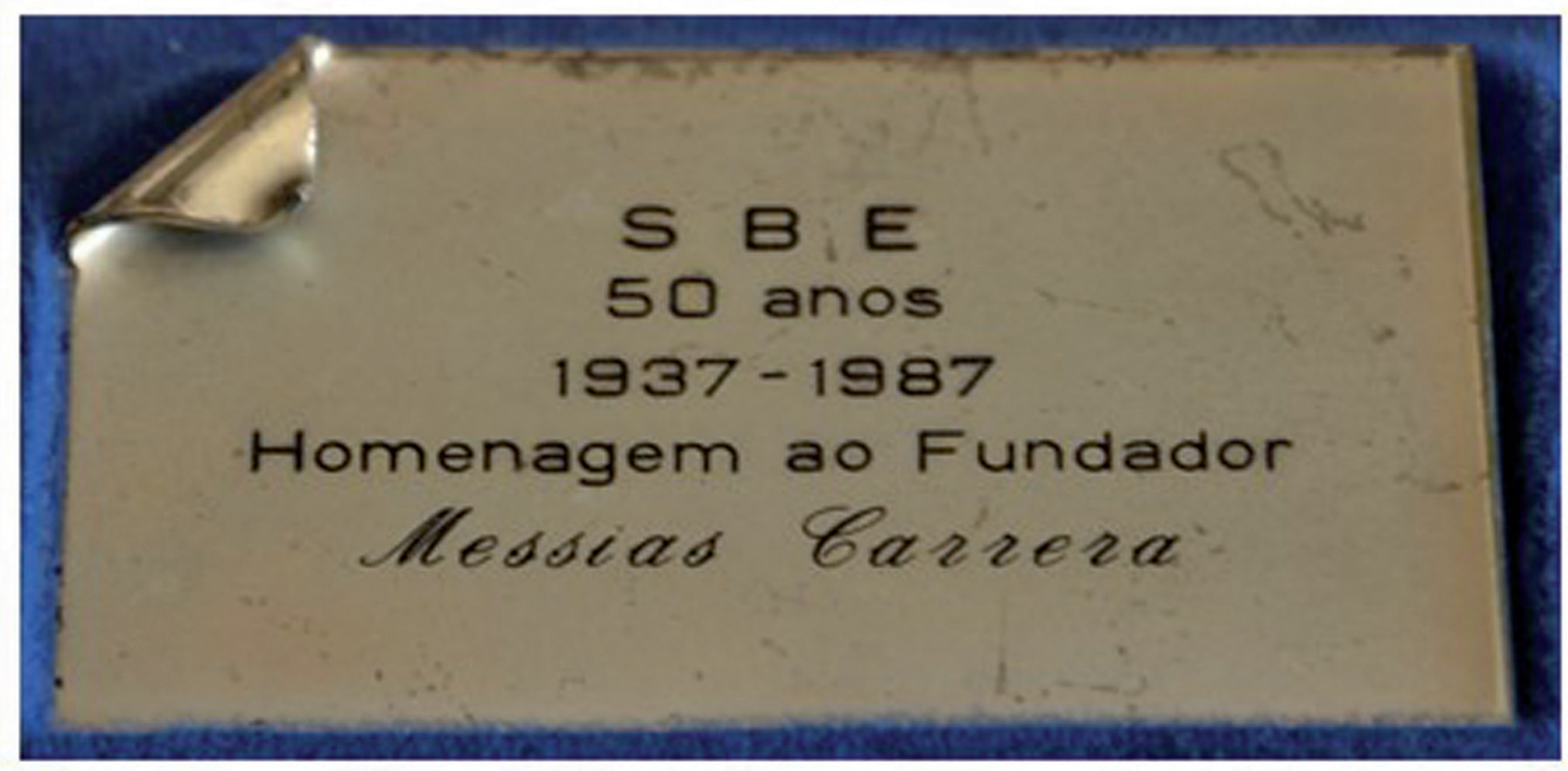

Figure 7. Honor plaque to Messias Carrera, a founding member of the Sociedade Entomológica do Brasil (1987).

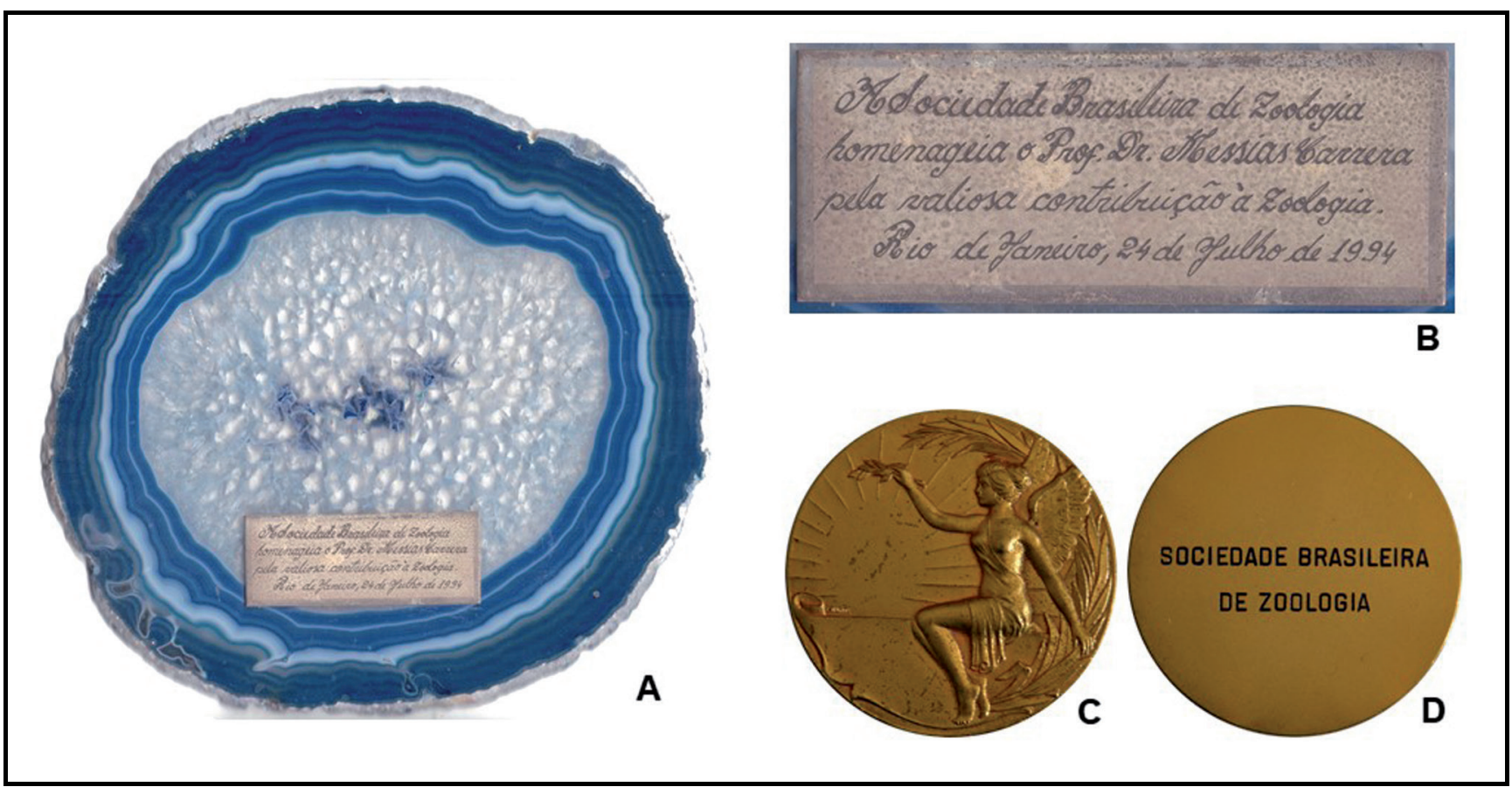

Figure 8. Plate (A) and medal (C and D) as an honor made by the Sociedade Brasileira de Zoologia to Messias Carrera, in 1994. Detail of the plate (B). 


\section{MOSCAS ASSASSINAS}

(ESPECIAL)

Entre a grande ordem dos Dipteros, uma familia existe que, pelos seus interessantes habitos, tem merecido especial atenção, não só do entomologista, como tambem daqueles que, embora desejando conhecer os fatos apenas na sua superficialidade, possuem entretanto, um gosto particular pelas cousas da Natureza. Refiro-me aos Dipteros da familia Asilidae, dos quais é meu intento divulgar algumas particularidades neles observadas.
Os asilideos se caracterisam, principalmeote, pela forma da cabeça que é achatada no. sentido antero-posterior e com uma forte excevação na parte compreendida entre as antenas e os ocelos; partes bucais adaptadas $\mathbf{a}$ perfuração e sucção; corpo geralmente coberto de pelos e cerdas; permas fortes, as vezes longas, munidas de poderosas garras. De um modo' geral são de compleição robusta e de grande. velocidade no vộo.

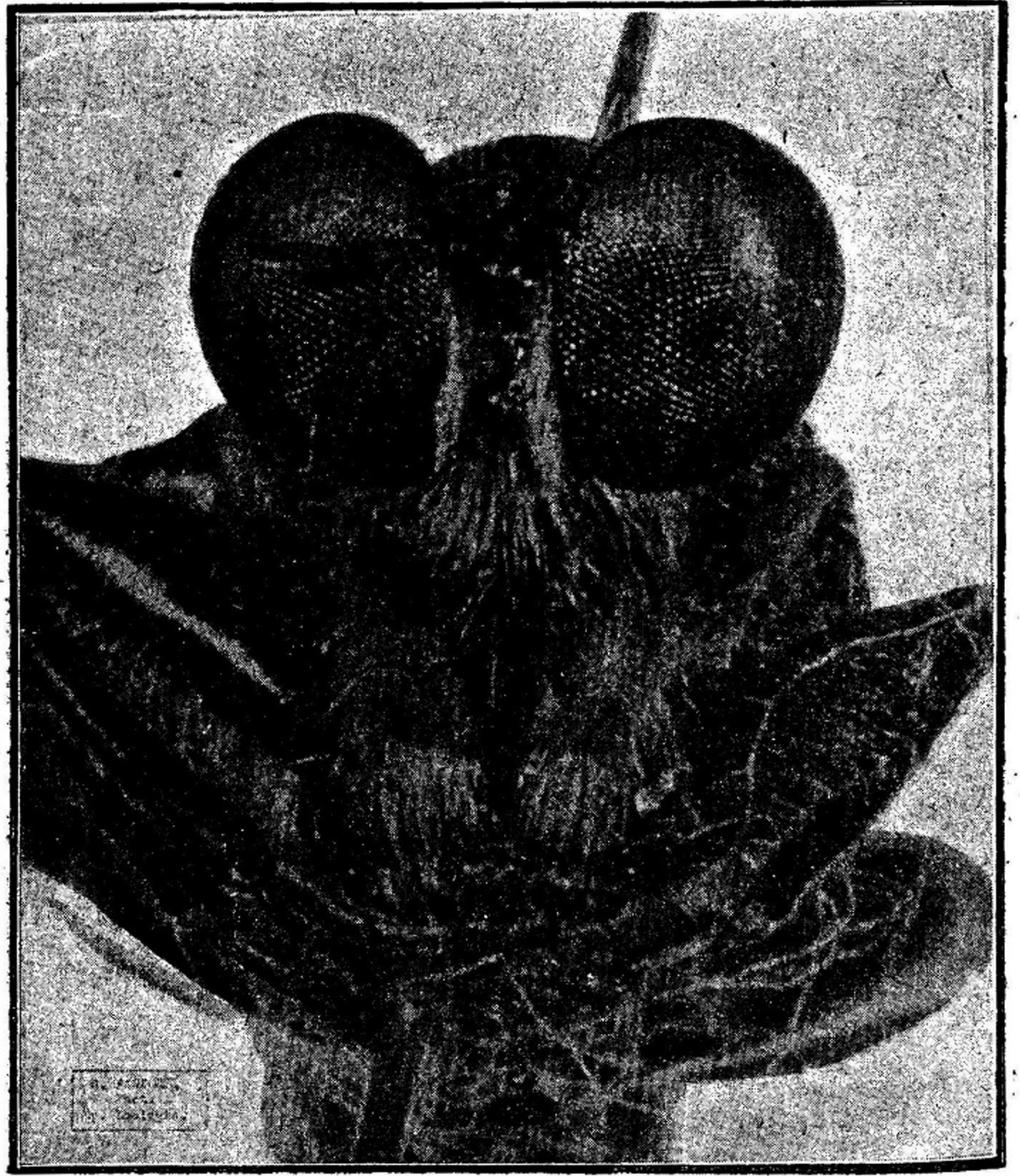

Fig. 1 - Cabeça de um asilideo onde se vê a forte excavação da sua parte superior (fronte). (vista de frente)

Figure 9. First page of the article Moscas Assassinas (Robber Flies) by Messias Carrera, published in 1939 in the magazine Chácaras e Quintais. 
es, nine translations, nine entomological entries for the encyclopedia Mirador Internacional, in addition to $11 \mathrm{sci}-$ ence communication titles.

In the present article, a total of 295 titles were inventoried. To facilitate their analysis, these were grouped according to their objective into eight categories, being these and their respective quantities: scientific article, 66; science communication, 170; didactic material, seven; bibliographical review, 22; obituary and biography, six; response to letters from readers of Chácaras e Quintais, eight; translation of books, nine; varied themes, seven (Fig. 10). The amount presented here may not yet reflect the actual number of publications by the author. This is justified by its usual publication in very low circulation journals, as in the case of Cultus (published by Colégio Anglo-Latino de São Paulo), Fauna, and O Moita, which have been preserved in a very restricted way. For these reasons, it is possible that some of his publications have not been retrieved. There is still the case of the section entitled No mundo dos insetos (In the world of insects) of the magazine Chácaras e Quintais, in which the author has provenly published some dissemination articles and answered the queries of readers, where the authorship is often not explicit. However, it is evident in Carrera (1991b) and Nomura (1995a, b) that the author published some articles for dissemination and answered questions from readers of that magazine. Nevertheless, the amount analyzed here is fully representative of the author's work, considering the amounts presented in the titles mentioned above.

Next, the information generated from the critical examination of Carrera's collected bibliographic production is presented. Therefore, the titles of the two most expressive categories were emphasized: scientific articles and science communication (Fig. 10). The total number of titles in these categories represents about $80 \%$ of the author's complete intellectual production. For these categories, the weighting will be made in relation to the relevance of these titles in their respective areas.

\section{Scientific Articles}

The 66 titles categorized as scientific articles represent about 22\% (Fig. 10) of Carrera's production, having been

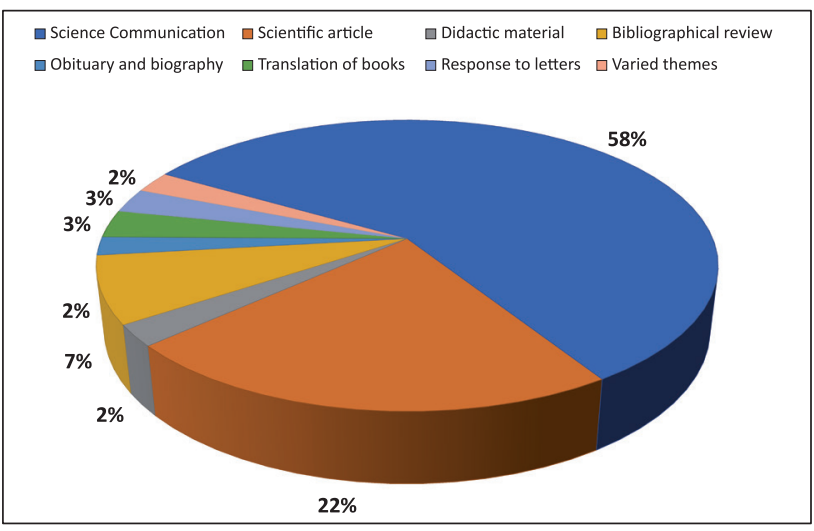

Figure 10. Representativeness of the categories by the objective of the titles that make up the work of Messias Carrera. published between 1940 and 1966 (Fig. 11) in 15 scientific journals, three of which were based outside Brazil. Most of these articles, approximately $75 \%$, were published without co-authors. However, in the others, Carrera shares co-authorship with several Brazilian researchers, such as Carlos Eduardo Machado-Allison, Hugo de Souza Lopes (1909-1991) (Oliveira, 1989), John Lane, Karol Lenko (1914-1975) (Nomura, 1991b), Lauro Pereira Travassos Filho, Lindolfo Rocha Guimarães (1908-1998), Maria Aparecida Vulcano d'Andretta, and Nelson Papavero.

Regarding the content, these articles deal exclusively with insects of the order Diptera present in the Neotropical Region. Eighteen families are approached, with the largest focus on Asilidae and Syrphidae, respectively, with $64 \%$ and $9 \%$ of representativeness (Fig. 12). As a rule, they deal with taxonomic issues such as redescription of species, descriptions of allotypes, immature forms, and new taxa, identification keys, and fauna survey. The organization of the articles follows the basic structure of a classic alpha taxonomy title, containing a brief introduction, a long descriptive section, and a brief discussion. In some cases, bionomic or feeding data is also available.

\section{Analysis of the taxa proposed by Messias Carrera}

A total of 154 new taxa were proposed by Carrera, of which 128 species, one subgenus, 24 genera, and one tribe. Approximately, an average of 2.4 new taxa was proposed per published article. Nine families are included, the most recurrent Asilidae (76\%), Syrphidae (8\%), and Bombylidae (6\%). Of the total, only 24 of the names proposed by the author have been synonymized so far (Fig. 13). Among all the author's scientific articles, the title Contribuição ao conhecimento dos Asilidae neotropicais (Diptera). I - Sobre as espécies brasileiras com esporão na tíbia (Contribution to the Neotropical Asilidae (Diptera) knowledge stands out. I - Brazilian species with spurs on the tibia) (Carrera, 1949a). A total of 36 new taxa are proposed, of which ten are not currently valid. Thus, it can be inferred that this title greatly impacted the taxonomy of the family Asilidae and can be considered one of the most important of the author's scientific production. The first article published by the author, in which new

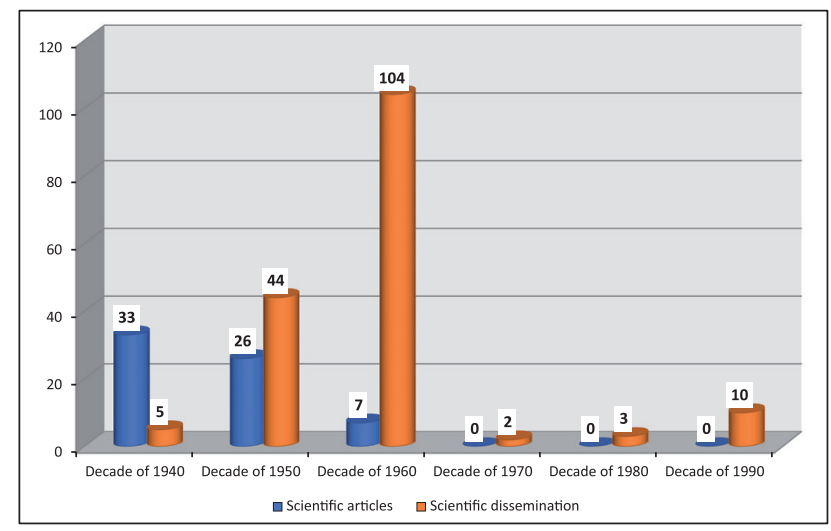

Figure 11. Comparison of the number of titles, categorized as scientific and scientific dissemination articles, published by Messias Carrera throughout his career. 


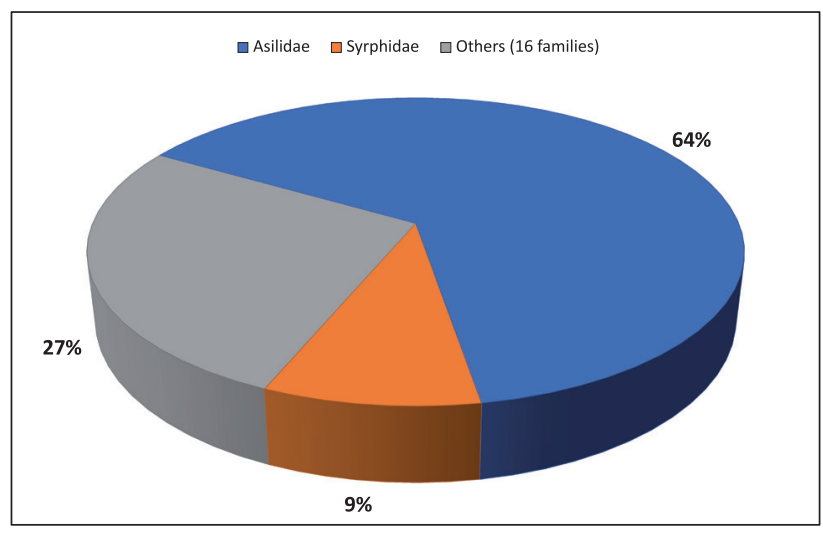

Figure 12. Proportion of the main families addressed in the scientific articles published by Messias Carrera.

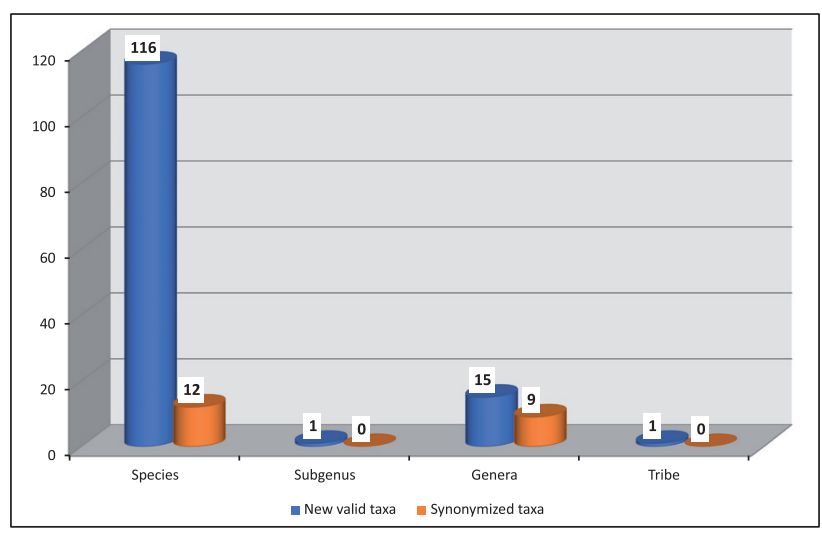

Figure 13. Quantitative of Diptera taxa, valid and synonymized, proposed by Messias Carrera.

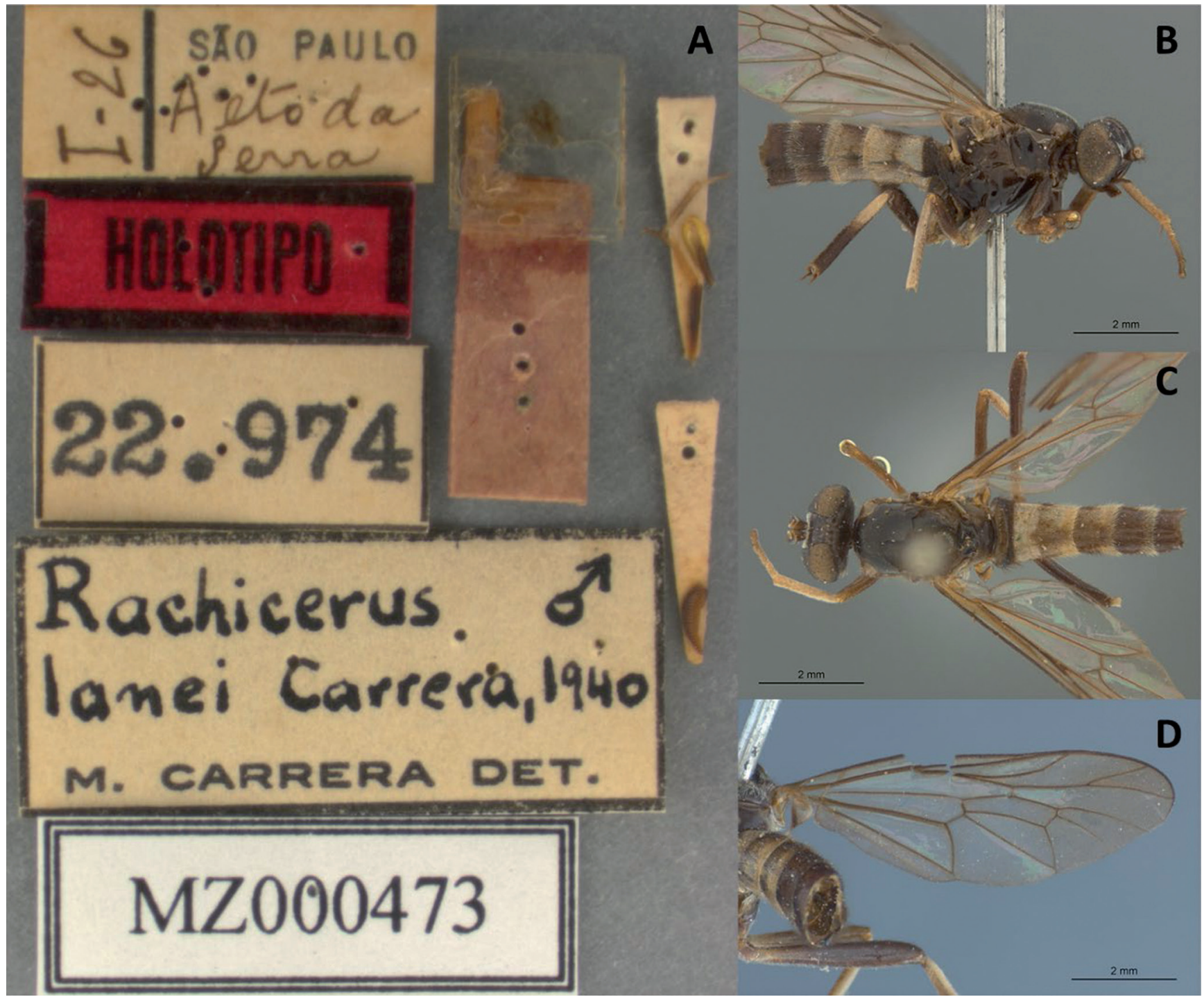

Figure 14. Board with photos of the first species described by Messias Carrera, Rachicerus lanei Carrera, 1940. (A) Holotype labels. (B) Photo of the holotype in a side view. (C) Photo of the holotype in dorsal view. (D) Detail of the wing of the holotype.

species were being described, was published in 1940 in the Arquivos de Zoologia do Estado de São Paulo (Carrera, 1940). In it, he described four new species, valid so far, all of the genus Rachicerus Walker, 1854, they are: $R$. Ianei Carrera, 1940 (Fig. 14); R. oliverioi Carrera, 1940; R. lopesi Carrera, 1940; R. marcusi Carrera, 1940.

\section{List of taxa proposed by Messias Carrera}

In this section, in addition to listing the names of the taxa proposed by Carrera, their current taxonomic status, original combination, type locality, and other information considered relevant are also presented. The 
data were surveyed from the original descriptions, from taxonomic review articles (e.g., Papavero, 2009) and from searches on the websites: Systema Dipterorum (Pape \& Thompson, 2013) and Catálogo Taxonômico da Fauna do Brasil (Rafael, 2017). The information referring to the type locality was transcribed as it was in the original descriptions, not having been checked or standardized, and, for this reason, may present spelling errors. The classification scheme used to structure the taxonomic list presented below follows that used by Carvalho et al. (2012).

\section{SUBORDEM BIBIONOMORPHA Hennig, 1954 ANISOPODIDAE Knab, 1912 ANISOPODINAE Knab, 1912}

Carreraia edwardsi (Carrera, 1941). (Original combination: Olbiogaster edwardsi). Status: valid. Type locality: Brazil, Paraná, Curitiba.

\section{SUBORDEM BRACHYCERA Macquart, 1834 ACROCERIDAE Leach, 1815 PANOPINAE Schiner, 1868}

Exetasis brasiliensis (Carrera, 1946) (Original combination: Pialeoidea brasiliensis). Status: valid. Type locality: Brazil, São Paulo, São Roque.

Pterodontia flavonigra Carrera, 1946. Status: valid. Type locality: Brazil, Santa Catarina, Caçador river.

\section{ASILIDAE Latreille, 1802 \\ ASILINAE Latreille, 1802}

Amblyonychus titan (Carrera, 1959) (Original combination: Promachina titan). Status: valid. Type locality: Bolivia, Chapare, Chipirirí river, $400 \mathrm{~m}$.

Amblyonychus yepezi (Carrera \& Machado-Allison, 1963) (Original combination: Promachina yepezi). Status: valid. Type locality: Venezuela, Bolívar, Guyaraca, Auyantepuy, 1.100 m.

Ctenodontina maya Carrera \& d'Andretta, 1953. Status: valid. Type locality: Peru, Huánuco, Tingo Maria, Huallaga river, $700 \mathrm{~m}$.

Eraxasilus Carrera, 1959. Status: valid. Type species: Eraxasilus pruinosus Carrera, 1959. Distribution: Neotropical Region.

Eraxasilus acuminatus Carrera, 1959. Status: valid. Type locality: Paraguay, Nueva Germania, Aguary Guazu river.

Eraxasilus pruinosus Carrera, 1959. Status: valid. Type locality: Brazil, São Paulo, Onda Verde, São João Farm.

Glaphyropyga aristata Carrera, 1950. Status: valid. Type locality: Panamá, Canal Zone, Barro Colorado island.

Glaphyropyga pollinifera Carrera, 1945. Status: valid. Type locality: Brazil, São Paulo, São Paulo.

Glaphyropyga venezuelensis Carrera \& MachadoAllison, 1963. Status: valid. Type locality: Venezuela, Aragua, Rancho Grande, $1.100 \mathrm{~m}$.
Lecania boraceae Carrera, 1958. Status: valid. Type locality: Brazil, São Paulo, Salesópolis, Estação Biológica de Boraceia.

Leinendera Carrera, 1945. Status: valid. Type species: Leinendera rubra Carrera, 1945. Distribution: Neotropical Region.

Leinendera rubra Carrera, 1945. Status: valid. Type locality: Brazil, Guanabara, Rio de Janeiro.

Lochmorhynchus albicans (Carrera \& d'Andretta, 1953) (Original combination: Erax albicans). Status: valid. Type locality: Peru, Lima, Pachacámac, near Lima.

Machimus bromleyanus (Carrera \& d'Andretta, 1950). (Original combination: Asilus bromleyanus). Status: valid. Type locality: México, Michoacán, Cerro Tancítaro.

Mallophora emiliae Carrera, 1960. Status: valid. Type locality: Brazil, Paraná, Curitiba.

Mallophora leucothrica Carrera \& d'Andretta, 1953. Status: valid. Type locality: Peru, Lima.

Mallophora mexicana Carrera, 1950. Status: junior synonym of Mallophora zita Curran, 1941. Ref. Artigas, Angulo (1980). Type locality: México, Nuevo Leon, Villa Santiago.

Nerax stigmosus (Carrera \& d'Andretta, 1950). (Original combination: Erax stigmosus). Status: valid. Type locality: México, Veracruz, Orizaba.

Promachus venustus Carrera \& d'Andretta, 1950. Status: valid. Type locality: México, San Luis Potosi, Valles El Bonito.

Pteralbis peregrinus (Carrera \& Machado-Allison, 1963) (Original combination: Neoitamus peregrinus). Status: valid. Type locality: Venezuela, Aragua, Rancho Grande.

Stenasilus Carrera, 1960. Status: valid. Type species: Stenasilus tenuis (Wiedemann, 1828) [Original combination: Asilus tenuis]. Distribution: Neotropical Region.

Threnia kelleri Carrera, 1952. Status: valid. Type locality: Brazil, São Paulo, Porto Cabral, Paraná river.

Threnia rabelloi Carrera, 1952. Status: valid. Type locality: Brazil, São Paulo, São Bento do Sapucaí.

\section{ANTOMOSIINI Lynch-Arribálzaga, 1882}

Atomosia fredericoi Carrera, 1952. Status: valid. Type locality: Brazil, São Paulo, São Paulo, Ipiranga.

Atomosia rosalesi Carrera \& Machado-Allison, 1963. Status: valid. Type locality: Venezuela, Carabobo, Mariara.

Atoniomyia fulvipes Carrera, 1946. Status: valid. Type locality: Brazil, Mato Grosso, Salobra.

Atoniomyia grossa Carrera, 1946. Status: valid. Type locality: Brazil, São Paulo, Severinia.

Hybozelodes acuticornis Carrera, 1945. Status: valid. Type locality: Brazil, Rio de Janeiro, Mangaratiba.

Hybozelodes clausicella (Carrera, 1960) (Original combination: Atractia clausicella). Status: valid. Type locality: Brazil, São Paulo, Cajurú.

Lycosimyia fluviatilis (Carrera, 1960) (Original combination: Atractia fluviatilis). Status: valid. Type locality: Brazil, Pará, Óbidos. 


\section{DASYPOGONINAE Macquart, 1838 DASYPOGONINI Macquart, 1838}

Aczelia Carrera, 1955. Status: valid. Type species: Aczelia argentina (Wulp, 1882) [Original combination: Laparus argentinus]. Distribution: Neotropical Region.

Amorimius barrettoi (Carrera, 1949). (Original combination: Macrocolus barrettoi). Status: valid. Type locality: Brazil, Minas Gerais, Araçuaí.

Amorimius rubripes (Carrera \& Papavero, 1962) (Original combination: Macrocolus rubripes). Status: valid. Type locality: Brazil, São Paulo, Campos do Jordão, Eugênio Lefèvre.

Araiopogon Carrera, 1949. Status: junior synonym of Saropogon Loew, 1847. Ref. Artigas, Papavero (1988).

Austenmyia Carrera, 1955. Status: valid. Type species: Austenmyia amazona Carrera, 1955. Distribution: Neotropical Region.

Austenmyia amazona Carrera, 1955. Status: valid. Type locality: Brazil, Amazonas, Manaus.

Cleptomyia Carrera, 1949. Status: valid. Type species: Cleptomyia bacillifera Carrera, 1949. Distribution: Neotropical Region.

Cleptomyia bacillifera Carrera, 1949. Status: junior synonym of Cleptomyia tripartita (Walker, 1854). Ref. Papavero (1971). Type locality: Brazil, Ceará, Russas.

Oberon Carrera \& Papavero, 1962. Status: junior synonym of Saropogon Loew, 1847. Ref. Artigas, Papavero (1988).

Saropogon melisoma (Carrera \& Papavero, 1962) (Original combination: Araiopogon melisoma). Status: valid. Type locality: Argentina, Tucuman.

Saropogon velutinus (Carrera \& Papavero, 1962) (Original combination: Oberon velutinus). Status: valid. Type locality: Argentina, Misiones, Loreto.

Tocantinia Carrera, 1955. Status: valid. Type species: Tocantinia misera (Walker, 1854) [Original combination: Dasypogon misera]. Distribution: Neotropical Region.

\section{DASYTRICHINI Lynch-Arribálzaga, 1882}

Alipiolaphria Carrera, 1955. Status: junior synonym of Cryptomerynx Enderlein, 1914. Ref. Artigas, Papavero, Pimentel (1988).

Cryptomerynx mirandai (Carrera, 1955) (Original combination: Alipiolaphria mirandai). Status: valid. Type locality: Brazil, Paraná, Curitiba.

Smeryngolaphria seabrai Carrera, 1960. Status: valid. Type locality: Brazil, Guanabara, Rio de Janeiro, Tijuca Forest.

\section{ISOPOGONINI Hardy, 1948}

Alvarenga Carrera, 1960. Status: valid. Type species: Alvarenga icarius Carrera, 1960. Distribution: Neotropical Region.

Alvarenga icarius Carrera, 1960. Status: valid. Type locality: Brazil, Paraíba, Soledade, Juazeirinho.
Aphamartania pritchardi Carrera, 1943. Status: junior synonym of Aphamartania maculipennis (Macquart, 1838) [Original combination: Dasypogon maculipennis]. Type locality: Brazil, Paraná, Curitiba. Ref. Papavero (1971).

Aspidopyga Carrera, 1949. Status: valid. Type species: Aspidopyga cophuroides Carrera, 1949. Distribution: Neotropical Region.

Aspidopyga cophuroides Carrera, 1949. Status: valid. Type locality: Brazil, Rio de Janeiro, Palmeiras.

Cophura picta Carrera, 1955. Status: valid. Type locality: "Ecuador".

\section{LAPHRIINI Macquart, 1838}

Ichneumolaphria Carrera, 1955. Status: valid. Type species: Ichneumolaphria zikani Carrera, 1955. Distribution: Neotropical Region.

Ichneumolaphria zikani Carrera, 1955. Status: valid. Type locality: Brazil, Minas Gerais, Virgínia, 900 m.

Rhopalogaster araujoi Carrera, 1952. Status: valid. Type locality: Brazil, Goiás, Campinas.

\section{LAPHYSTIINAE Hendel, 1936}

Apoxyria americana Carrera, 1955. Status: valid. Type locality: Brazil, Goiás, Corumbá.

Macahyba Carrera, 1947. Status: valid. Type species: Macahyba nordestina Carrera, 1947. Distribution: Neotropical Region.

Macahyba nordestina Carrera, 1947. Status: valid. Type locality: Brazil, Ceará, Icó.

\section{LASTAURINI Papavero, 1973}

Blepharepium lynchi Carrera, 1949. Status: junior synonym of Blepharepium cajennense coarctatum (Perty, 1833). Ref. Papavero, Bernardi (1973). Type locality: Argentina, Delta, Abra Vieja.

Caenarolia anomala (Carrera, 1947) (Original combination: Diogmites anomalus). Status: valid. Type locality: Brazil, São Paulo, São Paulo, Ipiranga.

Caenarolia spitzi Carrera, 1949. Status: junior synonym of Caenarolia castigans (Walker, 1851). Ref. Artigas, Papavero (1988). Type locality: Brazil, Minas Gerais, Araguari.

Diogmites alvesi Carrera, 1949. Status: valid. Type locality: Brazil, Rio Grande do Norte, Natal.

Diogmites amethystinus Carrera, 1953. Status: valid. Type locality: Colombia, Meta, Restrepo, $500 \mathrm{~m}$.

Diogmites aureolus Carrera \& Papavero, 1962. Status: valid. Type locality: Argentina, Entre Rios.

Diogmites bifasciatus Carrera, 1949. Status: valid. Type locality: Brazil, São Paulo, Juquiá.

Diogmites bromleyi Carrera, 1949. Status: valid. Type locality: Brazil, Minas Gerais, Cambuquira.

Diogmites imitator Carrera, 1953. Status: valid. Type locality: Brazil, Pará. 
Diogmites obscurus Carrera, 1949. Status: valid. Type locality: Brazil, Goiás.

Diogmites parvus Carrera, 1948. Status: junior synonym of Diogmites inclusus (Walker, 1851). Ref. Carrera, Papavero (1962), Papavero (2009). Type locality: Brazil, Amazonas, Parauari river.

Diogmites superbus Carrera, 1953. Status: valid. Type locality: Costa Rica, Turrialba, $620 \mathrm{~m}$.

Diogmites vulgaris Carrera, 1947. Status: valid. Type locality: Brazil, São Paulo, Guatapara.

Diogmites wygodzinskyi Carrera, 1949. Status: valid. Type locality: Brazil, Rio de Janeiro, km 47 Rio-São Paulo.

Lastaurax Carrera, 1949. Status: junior synonym of Neodiogmites Carrera, 1949. Ref. Artigas, Papavero (1988).

Lastaurina biezankoi (Carrera \& Papavero, 1962) (Original combination: Lastauropsis biezankoi). Status: valid. Type locality: Brazil, Rio de Janeiro, Duque de Caxias.

Lastaurina travassosi (Carrera, 1949). (Original combination: Lastauronia travassosi). Status: valid. Type locality: Brazil, São Paulo, São Paulo.

Lastauroides Carrera, 1949. Status: junior synonym of Neodiogmites Carrera, 1949. Ref. Artigas, Papavero (1988).

Lastauronia Carrera, 1949. Status: junior synonym of Lastaurina Curran, 1934. Ref. Artigas, Papavero (1988).

Lastauropsis Carrera, 1949. Status: junior synonym of Lastaurus Loew, 1851. Ref. Artigas, Papavero (1988).

Lastaurus alticola Carrera \& Machado-Allison, 1966. Status: valid. Type locality: Bolivia, Cochabamba, Tiraque, $3.200 \mathrm{~m}$.

Lastaurus robustus Carrera, 1949. Status: valid. Type locality: Brazil, Minas Gerais, Araguari.

Lastaurus tricolor Carrera \& Machado-Allison, 1966. Status: valid. Type locality: Argentina, Tucumán, Araoz.

Lastaurus villosus (Carrera, 1949) (Original combination: Lastauropsis villosus). Status: valid. Type locality: Brazil, Paraná, Negro river.

Lastouroides albomarginatus (Carrera, 1949). Status: junior synonym of Neodiogmites niger (Carrera, 1949). Ref. Artigas, Papavero (1988). Type locality: Brazil, São Paulo, Alto da Serra (= Paranapiacaba).

Neodiogmites Carrera, 1949. Status: valid. Type species: Neodiogmites melanogaster (Wiedemann, 1821) [Original combination: Dasypogon melanogaster]. Distribution: Neotropical Region.

Neodiogmites alexanderi (Carrera, 1949) (Original combination: Lastauroides alexanderi). Status: valid. Type locality: Brazil, Rio de Janeiro, Angra dos Reis, Jucaral.

Neodiogmites atriapex (Carrera \& Papavero, 1962) (Original combination: Lastauroides atriapex). Status: valid. Type locality: Brazil, São Paulo, Araçatuba, Jacaretinga river.

Neodiogmites lanei (Carrera, 1949) (Original combination: Lastaurax lanei). Status: valid. Type locality: Brazil, Rio de Janeiro, Guanabara, São Paulo [?].
Neodiogmites mixtus (Carrera, 1949) (Original combination: Lastauroides mixtus) Status: valid. Type locality: Brazil, São Paulo, Campos do Jordão.

Neodiogmites modestus (Carrera, 1949) (Original combination: Lastauroides modestus). Status: valid. Type locality: Brazil, São Paulo, Campos do Jordão.

Neodiogmites niger (Carrera, 1949) (Original combination: Lastauroides niger). Status: Valid. Type locality: Brazil, Guanabara, Rio de Janeiro.

Neodiogmites tenebrosus Carrera, 1949. Status: valid. Type locality: Brazil, Bahia, Jequié.

Phonicocleptes langei Carrera, 1947. Status: junior synonym of Phonicoleptes longipes (Macquart, 1838) [Original combination: Dasypogon longipes]. Type locality: Brazil, Paraná, Vila Velha. Ref. Papavero (1971).

\section{LEPTOGASTRINAE Schiner, 1862}

Leptogaster titanus Carrera, 1958. Status: valid. Type locality: Brazil, São Paulo, Salesópolis.

Schildia fragilis (Carrera, 1944). (Original combination: Shannomyioleptus fragilis). Status: valid. Type locality: Brazil, Mato Grosso, Maracaju.

Shannomyioleptus Carrera, 1944. Status: junior synonym of Schildia Aldrich, 1923. Ref. Martin (1975).

MEGAPODINI Carrera, 1949. Status: valid. Genera type: Megapoda Macquart, 1834. Ref. Papavero (1975).

Cyrtophrys albimanus (Carrera, 1949) (Original combination: Mirolestes albimanus). Status: valid. Type locality: Brazil, Guanabara, Rio de Janeiro.

Pseudorus d'andrettae Carrera, 1949. Status: valid. Type locality: Brazil, São Paulo, Itaporanga.

Pseudorus hermanni Carrera, 1949. Status: valid. Type locality: Brazil [?].

Pseudoryclus Carrera, 1952. Status: junior synonym of Pseudorus Walker, 1851. Ref. Papavero (1975).

Senobasis almeidai Carrera, 1946. Status: valid. Type locality: Brazil, São Paulo, Araraquara.

Senobasis boraceana Carrera, 1952. Status: junior synonym of Senobasis lanei Carrera, 1949. Ref. Papavero (1975). Type locality: Brazil, São Paulo, Salesópolis, Estação Biológica de Boracéia.

Senobasis bromleyana Carrera, 1949. Status: valid. Type locality: Brazil, São Paulo, Campos do Jordão.

Senobasis flukei Carrera, 1952. Status: valid. Type locality: Equador, Palmar, Menabi, $200 \mathrm{~m}$.

Senobasis Ianei Carrera, 1949. Status: valid. Type locality: Brazil, São Paulo, Campos do Jordão.

Senobasis lopesi Carrera, 1949. Status: junior synonym of Senobasis apicalis (Schiner, 1867). Ref. Papavero (1975). Type locality: Brazil, Rio de Janeiro, Teresópolis.

Senobasis rhombungulata Carrera, 1949. Status: junior synonym of Senobasis ornata (Wiedemann, 1838). Ref. Papavero (1975). Type locality: Brazil, Rio de Janeiro, Angra dos Reis.

Senobasis weyrauchi Carrera, 1952. Status: junior synonym of Senobasis notata (Bigot, 1878). Ref. Papavero (1975). Type locality: Peru, Pucalpa, 200 m. 


\section{STENOPOGONINAE Hull, 1962 ENIGMOMORPHINI Hull, 1962}

Creolestes keiseri (Carrera \& Papavero, 1965) (Original combination: Alyssomyia keiseri). Status: valid. Type locality: Chile, Valdivia, Panguipulli.

Dicranus nigerrimus Carrera, 1955. Status: valid. Type locality: Argentina, Estância Siete de abril.

Dizonias bromleyi Carrera, 1950. Status: junior synonym of Prolepsis tristis (Walker, 1851) [Original combination: Dasypogon tristis]. Ref. Papavero (2009). Type locality: México, Michoacan, Apatzingan.

Pritchardia lopesi Carrera \& Papavero, 1965. Status: valid. Type locality: Brazil, São Paulo, Campos do Jordão.

Prolepsis rosariana (Carrera, 1959) (Original combination: Tolmerolestes rosarianus). Status: valid. Type locality: Argentina, Rosario.

\section{TRIGONOMIMINAE Enderlein, 1914}

Holococephala curvicosta Carrera, 1958. Status: valid. Type locality: Brazil, São Paulo, Salesópolis, Estação Biológica de Boracéia.

Holococephala mogiana Carrera, 1955. Status: valid. Type locality: Brazil, São Paulo, Mogi das Cruzes.

Holococephala pectinata Carrera, 1955. Status: valid. Type locality: Brazil, Santa Catarina, Nova Teutônia.

Seabramyia Carrera, 1960. Status: valid. Type species: Seabramyia tijucana Carrera, 1960. Distribution: Neotropical Region.

Seabramyia tijucana Carrera, 1960. Status: valid. Type locality: Brazil, Guanabara, Rio de Janeiro; Alto da Boa Vista \& Tijuca Forest.

BOMBYLIIDAE Latreille, 1802

ANTHRACINAE Latreille, 1804

ANTHRACINI Latreille, 1804

Anthrax macquarti d'Andretta \& Carrera, 1952 (nom. nov. for Anthrax leucopyga Macquart, 1855, homonym of Anthrax leucopygus Macquart, 1840). Status: valid. Type locality: South America.

\section{APHOEBANTINI Becker, 1913}

Aphoebantus dentei d'Andretta \& Carrera, 1952. Status: valid. Type locality: Brazil, Acre, Iquirí river, km 49 of the Rio Branco-Abunã road.

\section{TOXOPHORINAE Schiner, 1868 SYTROPODINI Brauer, 1880}

Systropus currani Carrera \& d'Andretta, 1950. Status: valid. Type locality: Brazil, São Paulo.

Systropus lanei Carrera \& d'Andretta, 1950. Status: valid. Type locality: Brazil, São Paulo, São Paulo (Santo Amaro).
Systropus oldroydi Carrera \& d'Andretta, 1950. Status: valid. Type locality: Brazil, Santa Catarina, Nova Teutônia.

Systropus repertus Carrera \& d'Andretta, 1950. Status: valid. Type locality: Brazil, São Paulo, São Paulo (Santo Amaro).

\section{TOXOPHORINI Schiner, 1868}

Toxophora lepidocera (Carrera \& d'Andretta, 1950) (Original combination: Eniconeura lepidocera). Status: valid. Type locality: Brazil, São Paulo, Porto Cabral, Paraná river.

Toxophora pallida Carrera \& d'Andretta, 1950. Status: valid. Type locality: Brazil, Ceará, Quixadá.

Toxophora travassosi (Carrera \& d'Andretta, 1950) (Original combination: Eniconeura travassosi). Status: valid. Type locality: Brazil, São Porto Cabral, Paraná river.

Toxophora zikani (Carrera \& d'Andretta, 1950) (Original combination: Eniconeura zikani). Status: valid. Type locality: Brazil, Rio de Janeiro, Itatiaia.

EMPIDIDAE Latreille, 1804

Hilarempis rodriguezi Carrera, 1954. Status: valid. Type locality: Chile, Península de Magallanes.

MYDIDAE Latreille, 1809 APIOPHORINAE Papavero \& Wilcox, 1974

Paramydas Carrera, 1948. Status: valid. Type species: Paramydas igniticornis (Bigot, 1857) [Original combination: Mydas igniticornis]. Distribution: Neotropical Region.

\section{RHOPALIINAE Papavero \& Wilcox, 1974}

Pseudorhopalia mirandai (d'Andretta \& Carrera, 1955) (Original combination: Rhopalia mirandai). Status: valid. Type locality: Brazil, Ceará, Icó.

\section{OESTRIDAE Leach, 1815 CUTEREBRINAE Bau, 1906}

Baucuterebra Guimarães \& Carrera, 1941 (Subgenus of Metacuterebra Bau, 1929). Status: junior synonym of Metacuterebra Bau, 1929. Ref. [?].

Metacuterebra (Cuterebra) worontzowi Guimarães \& Carrera, 1941. Status: junior synonym of Metacuterebra detrudatrix (Clark, 1848). Ref. Guimarães, Papavero, 1999. Type locality: Brazil, Amazonas, Parauari river.

Metacuterebra almeidai (Guimarães \& Carrera, 1941) (Original combination: Cuterebra (Baucuterebra) 
almeidai). Status: valid. Type locality: Brazil, Amazonas, cachoeira Taurino.

Metacuterebra pessoai (Guimarães \& Carrera, 1941) (Original combination: Cuterebra (Metacuterebra) almeidai). Status: valid. Type locality: Brazil, Amazonas, Negro river.

SYRPHIDAE Latreille, 1802

ERISTALINAE Newman, 1834

CERIOIDINI Wahigren, 1909

Polybiomyia travassosi (Lane \& Carrera, 1943) (Original combination: Cerioides travassosi). Status: valid. Type locality: Brazil, São Paulo, Paraná river.

Sphiximorpha shannoni (Lane \& Carrera, 1943) (Original combination: Ceroides shannoni) Status: valid. Type locality: Brazil, São Paulo, Juquiá.

\section{CHRYSOGASTERINI Shannon, 1922}

Lepidomyia dionysiana (d'Andretta \& Carrera, 1952) (Original combination: Lepidostola dionysiana). Status: valid. Type locality: Brazil, Acre.

\section{ERISTALINI Newman, 1922}

Quichuana borgmeieri Lane \& Carrera, 1944. Status: valid. Type locality: Brazil, São Paulo, Horto.

\section{MERODONTINI Edwards, 1915}

Nausigaster shannoni Carrera, Lopes \& Lane, 1947. Status: junior synonym of Nausigaster bonariensis Lynch-Arribalzaga, 1892. Ref. Thompson, Vockeroth, Sedman (1976). Type locality: Brazil, Paraná, Iguaçu.

Nausigaster tuberculata Carrera, Lopes \& Lane, 1947. Status: valid. Type locality: Brazil, Paraná, Iguaçu.

Nausigaster vanzolinii d'Andretta \& Carrera, 1952. Status: valid. Type locality: Brazil, Acre.

\section{MICRODONTINAE Rondani, 1845}

Mixogaster lanei Carrera \& Lenko, 1958. Status: valid. Type locality: Brazil, São Paulo, Campos do Jordão.

Mixogaster lopesi Carrera \& Lenko, 1958. Status: valid. Type locality: Brazil, Pará, Belém, Aura.

Schizoceratomyia Carrera, Lopes \& Lane, 1947. Status: valid. Type species: Schizoceratomyia barretoi Carrera, Lopes, Lane, 1947. Distribution: Neotropical Region.

Schizoceratomyia barretoi Carrera, Lopes \& Lane, 1947. Status: valid. Type locality: Brazil, Goiás, Corumbá, Monjolinho Farm.

Schizoceratomyia flavipes Carrera, Lopes \& Lane, 1947. Status: valid. Type locality: Brazil, São Paulo, Alto da Serra, Parque Cajurú.

\section{XYLOPHAGIDAE Fallén, 1810 [RACHICERIDAE]}

Rachicerus Ianei Carrera, 1940. Status: valid. Type locality: Brazil, São Paulo, Alto da Serra.

Rachicerus lopesi Carrera, 1940. Status: valid. Type locality: Brazil, Rio de Janeiro: Corcovado.

Rachicerus marcusi Carrera, 1940. Status: valid. Type locality: Brazil, São Paulo, Alto da Serra.

Rachicerus oliverioi Carrera, 1940. Status: valid. Type locality: Brazil, São Paulo, Bananal (Bocaina).

Rachicerus shannoni Carrera, 1945. Status: valid. Type locality: Brazil, Guanabara, Rio de Janeiro.

\section{List of scientific articles (in chronological order)}

CARRERA, Messias. Descrição do alótipo de Baccha lanei Curran, 1936 (Syrphidae, Dipt.). Papéis Avulsos do Departamento de Zoologia, v. 1, p. 65-68. 1940.

CARRERA, Messias. Novas espécies do gênero Rachicerus Walk., 1854 (Dipt). Arquivos de Zoologia do Estado de São Paulo, v. 1, n. 13, p. 387-398. 1940.

CARRERA, Messias. Notas sobre o gênero Olbiogaster Osten Sacken, 1886 com a descrição de uma nova espécie (Fam. Anisopodidae, Dipt.). Papéis Avulsos do Departamento de Zoologia, v. 1, p. 193-202. 1941.

TRAVASSOS FILHO, Lauro P.; CARRERA, Messias. Xanthozona melanopyga (Wiedmann, 1830) (Diptera: Tachinidae) prodadora de Brassolis astyra Godart, 1824 (Lepidoptera: Brassolidae), praga das palmeiras. Dados bionômicos dos dois insetos e morfológicos do taquinídeo. Arquivos de Zoologia do Estado de São Paulo, v. 3, n. 3, p. 43-74. 1941.

GUIMARÃES, Lindolfo R.; CARRERA, Messias. Contribuição ao conhecimento dos Cuterebrídeos do Brasil. Arquivos de Zoologia do Estado de São Paulo, v. 3, n. 1, p. 1-12. 1941.

CARRERA, Messias. Algumas notas sobre Scenopinus Latreille, 1802 (Dipt.). Revista de Entomologia, v. 14, n. 3, p. 524-525. 1943.

CARRERA, Messias. Nova espécie de Aphamartania Schiner, 1866, de Curitiba (Dipt. Asilidae). Arquivos do Museu Paranaense, v. 3, p. 119-122. 1943.

LANE, John; CARRERA, Messias. Sobre o gênero Cerioides (Diptera, Syrphidae, Cerioidini). Revista de Entomologia, v. 14, n. 1-2, p. 168-173. 1943.

CARRERA, Messias. Chave sinóptica da subfamília Leptogastrinae (Diptera, Asilidae), com a descrição de um novo gênero e uma nova espécie. Papéis Avulsos do Departamento de Zoologia, v. 4, n. 6, p. 85-94. 1944.

CARRERA, Messias. Relação de alguns dípteros capturados em Monte Alegre, estado de São Paulo. Papéis Avulsos do Departamento de Zoologia, v. 6, n. 5, p. 37-50. 1944.

LANE, John; CARRERA, Messias. Duas espécies de Quichuana que se criam em bambu (Diptera, Syrphidae). Revista de Entomologia, v. 15, n. 1-2, p. 205-208. 1944.

CARRERA, Messias. Contribuição ao conhecimento do gênero Rachicerus Walk., 1854. (Diptera, Rachiceridae 
Handlirsch, 1908). Papéis Avulsos do Departamento de Zoologia, v. 5, n. 14, p. 119-134. 1945.

CARRERA, Messias. Estudo sobre os gêneros Glaphyropyga e Senoprosopis com descrição de novo gênero e nova espécie. Papéis Avulsos do Departamento de Zoologia, v. 5, n. 19, p. 175-192. 1945.

CARRERA, Messias. Pequenas notas sobre Asilidae (Diptera) I. Sobre algumas espécies do gênero Townsendia, Hypenetes, Aphamartania. II. Descrição de uma nova espécie de Hybozelodes (Laphriinae). Papéis Avulsos do Departamento de Zoologia, v. 5, n. 18, p. 167-174. 1945.

CARRERA, Messias. Relação de alguns Asilidae (Diptera) com suas presas. Papéis Avulsos do Departamento de Zoologia, v. 5, n. 17, p. 159-166. 1945.

CARRERA, Messias; LANE, John. Diptera de Caiobá (Est. do Paraná) (Diptera, Stratiomyiidae e Tabanidae). Arquivos do Museu Paranaense, v. 4, p. 127-136. 1945.

CARRERA, Messias. Duas novas espécies de Cyrtidae (Diptera) do Brasil. Papéis Avulsos do Departamento de Zoologia, v. 7, n. 5, p. 79-86. 1946.

CARRERA, Messias. Nova espécie de Senobasis Macq., 1836 (Diptera, Asilidae). In: Lane, Frederico; Guimarães, Lindolfo R. (Eds.). Livro de Homenagem a Romualdo Ferreira d'Almeida. São Paulo: Sociedade Brasileira de Entomologia, p. 121-124. 1946.

CARRERA, Messias. Pequenas notas sobre Asilidae III Redescrição de Dissmeryngodes anticus (Wied.) e descrição do alótipo de Othoniomyia triangularis Hermann (Laphriinae, Athomosiini). Papéis Avulsos do Departamento de Zoologia, v. 7, n. 7, p. 93-100. 1946.

CARRERA, Messias. Sobre algumas espécies do gênero Atoniomyia Hermann, 1912 (Diptera, Asilidae). Papéis Avulsos do Departamento de Zoologia, v. 7, n. 9, p. 113-128. 1946.

CARRERA, Messias. Sobre o gênero Cerozodus Bigot, 1857 (Diptera, Asilidae). Papéis Avulsos do Departamento de Zoologia, v. 7, n. 22, p. 247-256. 1946.

CARRERA, Messias. Asilideos coligidos no Paraguai pela missão científica brasileira (Diptera). Papéis Avulsos do Departamento de Zoologia, v. 8, n. 3, p. 39-48. 1947.

CARRERA, Messias. Novo gênero e nova espécie de Asilidae (Diptera) do nordeste brasileiro. Papéis Avulsos do Departamento de Zoologia, v. 8, n. 17, p. 203-208. 1947.

CARRERA, Messias. Segunda relação de alguns Asilidae (Diptera) e suas presas, com descrição prévia de duas novas espécies. Papéis Avulsos do Departamento de Zoologia, v. 8, n. 23, p. 265-271. 1947.

CARRERA, Messias. Sobre o gênero Leptopteromyia Williston, 1908 (Diptera, Asilidae). Papéis Avulsos do Departamento de Zoologia, v. 8, n. 7, p. 89-96. 1947.

CARRERA, Messias; TRAVASSOS FILHO, Lauro P. Dados morfológicos e bionômicos sobre Hylemyia poeciloptera (Malloch, 1921) (Diptera: Anthomyidae), minadoras das folhas de beterraba (Beta vulgaris L.). Papéis Avulsos do Departamento de Zoologia, v. 8, n. 4, p. 49-60. 1947.

CARRERA, Messias; LOPES, Hugo S.; LANE, John. Contribuição ao conhecimento dos Microdontinae neotropicos e descrição de duas novas espécies de "Nausigaster" Williston (Diptera, Syrphidae). Revista Brasileira de Biologia, v. 7, n. 4, p. 471-486. 1947.

CARRERA, Messias; LOPES, Hugo S.; LANE, John. Um novo gênero e duas espécies de Microdontinae (Diptera Syrphidae). Brasil-Médico, v. 51, n. 27-28, p. 1-5. 1947.

CARRERA, Messias; D'ANDRETTA, Maria A.V. Descrição de um novo gênero de Mydidae do Chile e redescrição do gênero Megascelus (Apioceratidae) (Diptera). Revista de Entomologia, v. 19, n. 3, p. 489-497. 1948.

CARRERA, Messias. Sobre as espécies de Diogmites da fauna amazônica (Diptera, Asilidae). Boletim do Museu Paraense Emílio Goeldi, v. 10, p. 115-122. 1948.

CARRERA, Messias. Sobre o gênero Lycomyia Bigot, 1857 (Diptera, Asilidae). Revista de Entomologia, v. 19, n. 3, p. 423-428. 1948.

CARRERA, Messias. Contribuição ao conhecimento dos Asilidae neotropicais (Diptera). I. Sobre as espécies brasileiras com esporão na tíbia. Arquivos de Zoologia do Estado de São Paulo, v. 7, n. 1, p. 1-148. 1949.

TRAVASSOS FILHO, Lauro P.; CARRERA, Messias. Contribuição para o conhecimento de "Pseudogaurax longilineatus" Sabrosky, parasita de ooteca de "Mantodea" (Diptera, Chloropidae). Revista Brasileira de Biologia, v. 9, n. 1, p. 97-101. 1949.

CARRERA, Messias. Asilideos da Argentina (Diptera) I Sobre o gênero Prolepsis Walker, 1851. Dusenia, v. 1, n. 2, p. 83-90. 1950.

CARRERA, Messias. Sobre o gênero Plugiocephalus Widernann, 1830 (Diptera, Otitidae, Plerocallidae). Papéis Avulsos do Departamento de Zoologia, v. 9, n. 17, p. 259-268. 1950.

CARRERA, Messias. Synoptical keys for the genera of Brasilian "Asilidae" (Diptera). Revista Brasileira de Biologia, v. 10, n. 1, p. 99-111. 1950.

CARRERA, Messias. Uma nova espécie de Glaphyropyga da zona do canal do Paraná (Diptera, Asilidae). Dusenia, v. 1, n. 1, p. 27-32. 1950.

CARRERA, Messias; D'ANDRETTA, Maria A.V. Asilideos do México (Diptera). Papéis Avulsos do Departamento de Zoologia, v. 9, n. 12, p. 159-191. 1950.

CARRERA, Messias; D'ANDRETTA, Maria A.V. Sobre as espécies brasileiras de Systropus Widernann, 1830 (Diptera, Bombyliidae). Papéis Avulsos do Departamento de Zoologia, v. 9, n. 20, p. 295-319. 1950.

D'ANDRETTA, Maria A.V.; CARRERA, Messias. Sobre as espécies brasileiras de Toxophorinae (Diptera, Bombyliidae). Dusenia, v. 1, n. 6, p. 351-374. 1950.

CARRERA, Messias. Pequenas notas sobre Asilidae (Diptera). IV. Descrição de duas novas espécies de Atomosia e Rhopalogaster. Papéis Avulsos do Departamento de Zoologia, v. 10, n. 10, p.209-212.1952.

CARRERA, Messias. Sobre a tribo Megapodini (Diptera, Asilidae, Dasypogoninae). Arquivos de Zoologia do Estado de São Paulo, v. 8, n. 2, p. 53-58. 1952.

CARRERA, Messias. Sobre o gênero Theria Schiner, 1866 (Diptera, Asilidae). Papéis Avulsos do Departamento de Zoologia, v. 10, n. 12, p. 235-252. 1952.

CARRERA, Messias; D'ANDRETTA, Maria A.V. Relação de alguns Asilidae e suas presas (III). Papéis 
Avulsos do Departamento de Zoologia, v. 10, n. 13, p. 253-259. 1952.

D'ANDRETTA, Maria A.V.; CARRERA, Messias. Resultados de uma expedição científica ao território do Acre Diptera. Papéis Avulsos do Departamento de Zoologia, v. 10, n. 17, p. 293-306. 1952.

CARRERA, Messias. As espécies neotrópicas do gênero Diogmites (Diptera, Asilidae). Arquivos de Zoologia do Estado de São Paulo, v. 8, n. 6, p. 169-207. 1953.

CARRERA, Messias. Pequenas notas sobre Asilidae (Diptera). V. Sobre alguns Dasypogoninae das coleções do Museu Britânico e do Instituto Miguel Lillo. Papéis Avulsos do Departamento de Zoologia, v. 11, n. 6, p. 271-277. 1953.

CARRERA, Messias; D'ANDRETTA, Maria A.V. Asilideos do Peru (Diptera). Papéis Avulsos do Departamento de Zoologia, v. 11, n. 9, p. 63-78. 1953.

CARRERA, Messias. Sobre alguns Empididae (Diptera) da Península de Magalhães, Chile. Revista Brasileira de Entomologia, v. 1, p. 221-226. 1954.

CARRERA, Messias. Asilideos da Argentina (Diptera). II. Aczelia, novo gênero para Laparus argentinus Wulp, 1882. Papéis Avulsos do Departamento de Zoologia, v. 12, n. 14, p. 297-302. 1955.

CARRERA, Messias. Novos gêneros e novas espécies de Dasypogoninae neotropicais (Diptera, Asilidae). Papéis Avulsos do Departamento de Zoologia, v. 12, n. 2, p. 99-118. 1955.

CARRERA, Messias. Sobre alguns gêneros da tribo Laphiriini (Diptera, Asilidae). Arquivos do Museu Nacional, v. 42, p. 113-121. 1955.

CARRERA, Messias. Sobre o gênero Dicranus Loew, 1851 (Diptera, Asilidae). Papéis Avulsos do Departamento de Zoologia, v. 12, n. 10, p. 235-246. 1955.

D'ANDRETTA, Maria A.V.; CARRERA, Messias. Sobre alguns Mydaidae do Brasil (Diptera). Arquivos do Museu Nacional, v. 42, p. 7-20. 1955.

CARRERA, Messias; D'ANDRETTA, Maria A.V.Sobre a família Pantophtalmidae (Diptera). Arquivos de Zoologia do Estado de São Paulo, v. 10, n. 4, p. 253-330. 1957.

CARRERA, Messias. Dipteros de Boraceia I. Asilidae. Papéis Avulsos do Departamento de Zoologia, v. 13, n. 12, p. 141-154. 1958.

CARRERA, Messias. Sobre o gênero Dasyllis Loew, 1851 (Diptera, Asilidae). Papéis Avulsos do Departamento de Zoologia, v. 13, n. 16, p. 213-220. 1958.

CARRERA, Messias; LENKO, Karol. Descrição de duas espécies novas de Mixogaster (Diptera, Syrphidae) e observações sobre o inquilinismo de uma delas em ninhos de Iridomyrmex humilis, a "formiga argentina". Studia Entomologica, v. 1, n. 3/4, p. 465-486. 1958.

CARRERA, Messias. Sobre alguns Asilideos neotropicais (Diptera) do "Zoologische Sammlung des Bayerischen Staats". Opuscula Entomologia, v. 30, p. 1-13. 1959.

CARRERA, Messias. Asilidae (Diptera) da coleção Seabra. Arquivos de Zoologia do Estado de São Paulo, v. 11, n. 7, p. 147-169. 1960.

CARRERA, Messias. Asilidae (Diptera) do Uruguay e regiones circunvizinhas. Revista de la Sociedad Uruguaya de Entomología, v. 4, p. 43-53. 1960.
CARRERA, Messias; D'ANDRETTA, Maria A.V. Relação de alguns Asilidae (Diptera) e suas presas (IV). Revista Brasileira de Entomologia, v. 10, p. 67-81. 1961.

CARRERA, Messias; PAPAVERO, Nelson. Saropogonini neotropicais (Diptera, Asilidae, Dasypogoninae). Studia Entomologica, v. 5, n. 1-4, p. 39-64. 1962.

CARRERA, Messias., MACHADO-ALLISON, Carlos E. Contribución al conocimiento de los Asilidae (Diptera) de Venezuela. Acta Biologica Venezuelica, v. 3, n. 15, p. 233-267. 1963.

CARRERA, Messias; PAPAVERO, Nelson. Sobre os gêneros Pritchardia Stuardo, Alyssomyia Hull e Hypenetes Loew (Diptera, Asilidae). Papéis Avulsos do Departamento de Zoologia, v. 18, n. 6, p. 47-55. 1965.

CARRERA, Messias; MACHADO-ALLISON, Carlos E. Sobre el genero Lastaurus Loew, 1851 (Dipt., Asilidae). Boletín de la Sociedad Venezolana de Ciencias Naturales, v. 110, p. 483-503. 1966.

\section{Taxa of Diptera order named in honor of Messias Carrera}

Nomura (1995a) presents a survey of the taxa of the Diptera order named in honor of Carrera. Having found some inconsistencies, an updated and rectified version of this survey is presented below. For this, the information contained in the database of the Systema Dipterorum, website (www.diptera.org, accessed in August 2017) and, when necessary, in the original descriptions of the respective taxa, were used.

1. Carreraia Correa, 1947 (Anisopodidae)

2. Pegomya carrerai Albuquerque, 1959 (Anthomyiidae)

3. Carreraomyia Cole, 1969 (nom. nov. for Carreraia Cole \& Pritchard, 1964) (Asilidae)

4. Catostola carrerai Hull, 1958 (Asilidae)

5. Ctenodontina carrerai (Hull, 1958) - Original combination: Catostola carrerai (Asilidae)

6. Doryclus carrerai Bromley, 1958 (Asilidae)

7. Glaphyropyga carrerai Ayala, 1983 (Asilidae)

8. Lycosimyia carrerai d'Andretta, 1951 (Asilidae)

9. Neodiogmites carrerai Artigas \& Papavero, 1988 (Asilidae)

10. Palpomyia carrerai (Lane, 1948) - Original combination: Dicrobezzia carrerai (Ceratopogonidae)

11. Stenoxenus carrerai Lane, 1956 (Ceratopogonidae)

12. Hippelates carrerai Paganelli \& Sabrosky, 1993 (Chloropidae)

13. Diathoneura carrerai (Frota-Pessoa, 1947) - Original combination: Clastopteromyia carrerai (Drosophilidae)

14. Dimecoenia carrerai Oliveira, 1957 (Ephydridae)

15. Rhamphomyia carrerai Smith, 1962 (Empididae)

16. Gonomyia (Lipophleps) carrerai Alexander, 1943 (Limoniidae)

17. Hexatoma (Eriocera) carrerai Alexander, 1942 (Limoniidae)

18. Mycetophila (Abmyceta) carrerai Lane, 1958 (Mycetophilidae)

19. Mycomya carrerai Coher, 1950 (Mycetophilidae)

20. Messiasia d'Andretta, 1951 (Mydidae) 
21. Messiasia carrerai d'Andretta, 1951 (Mydidae)

22. Glyphidops carrerai Aczel, 1961 (Neriidae)

23. Elmohardyia carrerai (Hardy, 1950) - Original combination: Dorilas carrerai (Pipunculidae)

24. Lutzomyia (Psychodopygus) carrerai (Barretto, 1946) - Original combination: Phlebotomus carrerai (Psychodidae)

25. Carrerapyrgota Aczél, 1956 (Pyrgotidae)

26. Somatia carrerai Papavero, 1962 (Somatiidae)

27. Carreramyia Doesburg, 1966 - junior synonym of Ubristes Walker, 1852 (Syrphidae)

28. Schizoceratomyia carrerai (Papavero, 1962) - Original combination: Masarygus carrerai (Syrphidae)

29. Archytas carrerai Guimarães, 1961 (Tachinidae)

30. Catachlorops carrerai Barretto, 1946 (Tabanidae)

31. Itacuphocera carrerai Guimarães, 1964 (Tachinidae)

32. Tomoplagia carrerai Aczel, 1955 (Tephritidae)

33. Leptotarsus (Longurio) carreranus (Alexander, 1945) - Original combination: Macromastix carreranus (Tipulidae)

34. Ozodicera (Ozodicera) carrerella Alexander, 1956 (Tipulidae)

35. Rachicerus carrerai Pujol-Luz, 2019 (Xylophagidae)

\section{Science communication}

Like Eurico Santos (1883-1968) (Straube, 2009) and those already mentioned José Reis and Karol Lenko, Carrera played an important role in Brazilian science communication in the mid-20 $0^{\text {th }}$ century. Most of his work, about 170 titles, approximately $60 \%$ (Fig. 10) of the total, is focused on disseminating and popularizing science, more specifically on the biology of insects. In contrast to his scientific production, his science communication titles were produced throughout his academic life (Fig. 11). Having no co-authors, most of them were published in newspapers of great circulation, such as Estado de São Paulo, Folha de S. Paulo, and Correio Paulistano, or amateur magazines, such as Chácaras e Quintais. Some others were published in scientific journals, such as Revista Brasileira de Entomologia, Revista Brasileira de Zoologia, and Revista Brasileira de Biologia, or as a participant of books. It is possible to identify a certain repetition of some titles, mainly taking into account different media (magazines, newspapers, and books). Analyzing such titles, one can notice certain adequacy, even if small, in relation to the target audience of the media in question, justifying such duplicity.

Among the titles included in this category, there are the Histórias de insetos series and the book Insetos, lendas e história, two sets that can be considered of great importance in the author's work. The first consists of 91 titles published weekly in the Folha de S. Paulo newspaper, between December 1963 and September 1965. This resulted from an invitation made to Carrera by José Reis (verbal information ${ }^{5}$, pioneer of scientific journalism

5 Information provided by Prof. Dr. Hitoshi Nomura and Mrs. Helena Carrera when being interviewed. and chief editor of the newspaper in question at the time (Moreira \& Massarani, 2002; Esteves, 2011). The second, the book Insetos, lendas e história, was published by the publishing house Thesaurus, from Brasília, in 1991. It gathers content from some of the author's previously published titles, mainly in the series mentioned above, but also in other media, with only one of the book's 40 chapters being considered unpublished. Subsequent publications of this research will focus on the Folha de S. Paulo newspaper series, as well as the book and other science communication titles, to contextualize Carrera's space-time work, taking into account the Brazilian social and cultural reality at that time.

\section{Titles published in scientific or amateur journals (54 titles)}

CARRERA, Messias. Moscas assassinas. Chácaras e Quintais, v. 60, n. 5, p. 620-623. 1939.

CARRERA, Messias. Alguma cousa sobre os dipteros da família Tipulidae. Chácaras e Quintais, v. 68, n. 3, p. 348-350. 1943.

CARRERA, Messias. O mosquito "Biriguí". Chácaras e Quintais, v. 70, n. 1, p. 48-50. 1944.

CARRERA, Messias. O Piolho das Abelhas. Chácaras $e$ Quintais, v. 70, n. 3, p. 308. 1944.

CARRERA, Messias. Moscas parasitas de aranhas. Chácaras e Quintais, v. 73, n. 2, p. 174-178. 1946.

CARRERA, Messias. Moscas Assassinas. Fauna, v. [?], n. [?], p. 15-16. 1952. [Published in July]

CARRERA, Messias. Insetos minadores de folhas. Boletim de Agricultura, São Paulo, v. [?], n. [?], p. 1-12. 1953.

CARRERA, Messias. Um besouro providencial. Fauna, v. [?], n. [?], p. 34-35. 1954. [Published in November]

CARRERA, Messias. A Zoologia nos dicionários. Fauna, v. [?], n. [?], p. 10[?]. 1955. [Published in January]

CARRERA, Messias. Milagre de São Bernardo. Fauna, v. [?], n. [?], p. 16-17. 1955. [Published in February]

CARRERA, Messias. Os insetos na medicina antiga. Chácaras e Quintais, v. 91, n. 5, p. 639-640. 1955.

CARRERA, Messias. A estranha morte do Imperador Tito. Chácaras e Quintais, v. 95, n. 3, p. [?]. 1956.

CARRERA, Messias. A derrota de Sapor II. Chácaras e Quintais, v. 93, n. 1, p. 123. 1956. [Section Entomologia pitoresca]

CARRERA, Messias. Um torneio de cítara na antiga Grécia. Chácaras e Quintais, v. 93, n. 3, p. 388. 1956. [Section Entomologia pitoresca]

CARRERA, Messias. Formigas. Chácaras e Quintais, v. 93, n. 2, p. 266-268. 1956. [Section No mundo dos insetos]

CARRERA, Messias. Gafanhotos. Chácaras e Quintais, v. 94, n. 1, p. 839-840. 1956. [Section No mundo dos insetos]

CARRERA, Messias. Inseto monstruoso. Chácaras e Quintais, v. 93, n. 2, p. 270-271. 1956. [Section No mundo dos insetos]

CARRERA, Messias. O berne e seu combate. Chácaras e Quintais, v. 94, n. 1, p. 68-70. 1956.

CARRERA, Messias. Os cupins e os homens da llha de Pitcairn. Chácaras e Quintais, v. 93, n. 2, p. 270. 1956. 
CARRERA, Messias. Percevejos. Chácaras e Quintais, v. 93 , n. 3, p. 381-383. 1956. [Section No mundo dos insetos]

CARRERA, Messias. Presente nupcial. Chácaras e Quintais, v. 94 , n. 3, p. 900-901. 1956. [Section No mundo dos insetos]

CARRERA, Messias. As moscas da madeira. Chácaras e Quintais, v. 95, n. 6, p. 817-820.1957.

CARRERA, Messias. Efemerídeos. Chácaras e Quintais, v. 96, n. 1, p. 60-62. 1957.

CARRERA, Messias. Os odores e os insetos. Chácaras e Quintais, v. 5, n. 2, p. 265. 1957. [Section No mundo dos insetos]

CARRERA, Messias. Piolhos. Chácaras e Quintais, v. 95, n. 4, p. 523-525. 1957. [Section No mundo dos insetos]

CARRERA, Messias. A morte de Mitrídates. Chácaras e Quintais, v. 97, n. 4, p. 460. 1958.

CARRERA, Messias. O Crucifixo de São Francisco Xavier. Chácaras e Quintais, v. 97, n. 5, p. 584. 1958.

CARRERA, Messias. Inseto "beijador", o futuro dono da Terra. Chácaras e Quintais, v. 99, n. 5, p. 595-596. 1959. [Section No mundo dos insetos]

CARRERA, Messias. O milagre de São Bernardo. Chácaras e Quintais, v. 99, n. 1, p. 52. 1959. [Section Entomologia pitoresca]

CARRERA, Messias. Peste, Ratos e Pulgas. Almanak Agrícola Brasileiro - Chácaras e Quintais, v. 100, n. 1, p. 312-318. 1959.

CARRERA, Messias. Bicho das Praias. Chácaras e Quintais, v. 102, n. 3, p. 536. 1960.

CARRERA, Messias. Insetos Minadores de Folhas. Chácaras e Quintais, v. 101, n. 4, p. 394-398. 1960. [Section No mundo dos insetos]

CARRERA, Messias. O mel tóxico de Xenofonte. Chácaras e Quintais, v. 101, n. 4, p. 424-435. 1960.

CARRERA, Messias. O mosquiteiro. Almanak Agrícola Brasileiro - Chácaras e Quintais, v. 104, n. 1, p. 227-232. 1961.

CARRERA, Messias. Os gafanhotos. Almanak Agrícola Brasileiro-Chácarase Quintais, v. 104, n. 1, p. 233. 1961.

CARRERA, Messias. A praga dos amaryllis. Chácaras $e$ Quintais, v. 106, n. 3, p. 395-397. 1962.

CARRERA, Messias. Insetos Sociais. Chácaras e Quintais, v. 108, n. 2, p. 263-268. 1963.

CARRERA, Messias. Libélulas. Chácaras e Quintais, v. 110, n. 6, p. 745-746. 1964.

CARRERA, Messias. Nem todos os insetos são "bandidos", alguns merecem monumento. Chácaras e Quintais, v. 112, n. 2, p. 331-334. 1965.

CARRERA, Messias. Insetos destruidores externos das plantas. Mundo Agrícola, v. [?], n. [?], p. 32-38. 1967. [Published in August]

CARRERA, Messias. Insetos destruidores internos das plantas. Mundo Agrícola, v. [?], n. [?], p. 39-42. 1967. [Published in August]

CARRERA, Messias. Insetos nocivos à agricultura. Mundo Agrícola, v. [?], n. [?], p. 33-38. 1967. [Published in August]

CARRERA, Messias. Insetos sugadores de plantas. Mundo Agrícola, v. [?], n. [?], p. 43-45. 1967. [Published in August]
CARRERA, Messias. História dos insetos inimigos dos livros. Ciência e Cultura, v. 33, n. 3, p. 353-361. 1981.

CARRERA, Messias. Nota sobre insetos utilizados como adorno. Revista Brasileira de Entomologia, v. 26, n. 1, p. 133-135. 1982

CARRERA, Messias. Migração de borboletas. Ciência e Cultura, v. 36, n. 1, p. 3-8. 1984.

CARRERA, Messias. Digressão sobre os nomes da barata. Revista Brasileira de Entomologia, v. 36, n. 2, p. 483-485. 1992.

CARRERA, Messias. Entomofagia humana. Revista Brasileira de Entomologia, v. 36, n. 4, p. 889-894. 1992.

CARRERA, Messias. As libélulas e seus mistérios. Revista Brasileira de Entomologia, v. 37, n. 3, p. 639-640. 1993.

CARRERA, Messias. A entomologia na história natural de Plínio. Revista Brasileira de Entomologia, v. 37, n. 2, p. 387-396. 1993.

CARRERA, Messias. Terapêutica entomológica. Revista Brasileira de Entomologia, v. 37, n. 1, p. 193-198. 1993.

CARRERA, Messias. Feromônios. Revista Brasileira de Entomologia, v. 38, n. 2, p. 507-508. 1994.

CARRERA, Messias. O amor canibal dos insetos. Revista Brasileira de Entomologia, v. 38, n. 3/4, p.777-779. 1994.

CARRERA, Messias. O gigantismo nos insetos. Revista Brasileira de Entomologia, v. 38, n. 1, p. 253-257. 1994.

CARRERA, Messias. Escarabeoideos Fúnebres e Sagrados. Revista Brasileira de Entomologia, v. 39, n. 2, p. 475-477. 1995.

CARRERA, Messias. O besouro bombardeiro. Revista Brasileira de Entomologia, v. 39, n. 2, p. 479-481. 1995.

CARRERA, Messias. Formigas fósseis. Chácaras e Quintais, v. [?], n. [?], p. [?]. 19[?].

\section{Articles published in daily newspapers ( 3 titles)}

CARRERA, Messias. O mosquito "Birigui". Jornal Correio da Manhã. Section Um pouco de Ciências, 4 Section, p. 1. 27 Oct. 1957. [v. LVII, n. 13314[?]]

CARRERA, Messias. Os gansos do Capitólio. O Moita, p. 6. [?] jan. 1970 [v. I, n. 4]

CARRERA, Messias. Migração de borboletas. O Estado de S. Paulo. Section Suplemento Cultural III, p. 15-16. 21 Oct. 1979 [n. 155]

\section{Articles that make up columns in daily newspapers (101 titles)}

List of titles published in the Sunday Supplement (section published only on Sundays) of the newspaper Correio Paulistano, São Paulo, SP, organized in chronological order of publication.

1. O mel que envenenou as tropas de Xenofonte. 08 August 1954, p. [?]

2. O Crucifixo de São Francisco Xavier. 29 August 1954, p. [?]

3. A morte de Mitridates. 12 September 1954, p. 3

4. Um telegrama funesto. 19 September 1954, p. [?] 
5. Um besouro providencial. 03 October 1954, p. [?]

6. Chuvas de sangue. 07 October 1954, p. [?]

7. A zoologia nos dicionários. 17 October 1954, p. [?]

8. Milagre de São Bernardo. 21 November 1954, p. [?]

9. A estranha morte do Imperador Tito. 06 December 1954, p. [?].

List of titles that compose the column Histórias de insetos published weekly in the Folha llustrada section (the section dealing with science, arts, and culture) of the Folha de S. Paulo newspaper, São Paulo, SP, organized in chronological order of publication.

1. Insetos vão ter história. Published in 10 December 1963. General news, p. 1 (cover) [Headline of the column]

2. Efeméridas não queriam deixar S. Bernardo falar e foram excomungadas. Published in 10 December 1963, p. 2

3. O olfato e a vista nos insetos florícolas. Published in 17 December 1963, p. 3

4. Cigarra tem cuíca para produzir som. Published in 24 December 1963, p. 5

5. "Rhodnius" poderá ser futuro dono da Terra. Published in 31 December 1963, p. 3

6. Os Epidideos dão presentes de núpcias antes do acasalamento. Published in 07 January 1964, p. 5

7. Há borboletas que voam mundo a fora. Published in 14 January 1964, p. 2

8. Na casa do Tricoptera podem ser encontradas até pepitas de ouro. Published in 21 January 1964, p. 5

9. Os progressos nos transportes trazem visitas indesejáveis. Published in 28 January 1964, p. 5

10. Jequiteranabóia é inofensiva; seu mal é ser demasiado feia. Published in 04 February 1964, p. 2

11. O caranguejo do crucifixo. Published in 11 February 1964 , p. 2

12. Nuvens de gafanhotos podem pesar até 70 t. Published in 19 February 1964, p. 2

13. Indústrias de anilinas desbancaram cochinilha. Published in 25 February 1964, p. 2

14. Chuvas de sangue podem ser obra de borboletas. Published in 03 March 1964, p. 5

15. O homem da pedra lascada já sabia apreciar o mel. Published in 10 March 1964, p. 6

16. Exércitos de mosquitos ganharam batalha contra o rei da Pérsia. Published in 17 March 1964, p. 5

17. Percevejo de cama, o terror da noite. Published in 24 March 1964, p. 2

18. As libélulas já foram até simbolo. Published in 31 March 1964, p. 10

19. Entomologista "morreu" sob nuvem de gafanhotos. Published in 07 April 1964, p. 2

20. "Mosquito palha". Published in 14 April 1964, p. 2

21. Lady Granville a primeira mulher que colecionou borboletas. Published in 21 April 1964, p. 2

22. No passado, piolhos elegiam prefeitos. Published in 28 April 1964, p. 5

23. Besouro salvou abade-entomologo. Published in 05 May 1964, p. 5
24. Picada das tocandiras servem para testar masculinidade dos índios. Published in 12 May 1964, p. 5

25. Minadores de folhas. Published in 19 May 1964, p. 2

26. Baratas domésticas figuram em cardápios. Published in 26 May 1964, p. 3

27. O Midas orelhudo é a maior mosca do mundo. Published in 02 June 1964, p. 3

28. Lenda diz que pulgas vieram das cinzas. Published in 09 June 1964, p. 2

29. O piolho das abelhas. Published in 16 June 1964, p. 6

30. A mosca do berne. Published in 23 June 1964, p. 8

31. A mosca das bicheiras. Published in 30 June 1964, p. 6

32. As picadas como máquinas de tortura. Published in 07 July 1964, p. 2

33. Besouro dos batatais em acusação internacional. Published in 14 July 1964, p. 6

34. Insetos como ornamento da indumentária feminina. Published in 21 July 1964, p. 8

35. Bicho da seda. Published in 28 July 1964, p. 8

36. Bicho da seda brasileiro. Published in 04 August 1964, p. 6

37. Gregos comiam cigarras; formiga é prato atual. Published in 11 August 1964, p. 6

38. A voracidade dos cupins. Published in 18 August 1964, p. 6

39. Vida social dos cupins. Published in 25 August 1964, p. 2

40. A vida social das abelhas e das formigas. Published in 01 September 1964, p. 6

41. Dicionários e insetos nem sempre estão de acordo. Published in 08 September 1964, p. 3

42. A cigarra na mitologia e na literatura. Published in 15 September 1964, p. 5

43. Um macróbio no mundo dos insetos. Published in 22 September 1964, p. 2

44. Moscas de ferro. Published in 29 September 1964, p. 5

45. Mariposa voraz danifica os Amarílis. Published in 06 October 1964, p. 2

46. O ninho da formiga saúva. Published in 13 October 1964, p. 2

47. "Arlequim das matas" tem pernas duas vezes maior que o corpo. Published in 20 October 1964, p. 3

48. Formigas deixam padre em má situação: demanda. Published in 27 October 1964, p. 3

49. Sereias do Mundo. Published in 03 November 1964, p. 3

50. Para o louva-deus o estômago está em primeiro lugar. Published in 10 November 1964, p. 6

51. Aves destruidoras de insetos sempre aparecem na hora certa. Published in 17 November 1964, p. 2

52. Homenagem ao besouro. Published in 24 November 1964, p. 6

53. A vespa de Uganda é protetora da agricultura. Published in 01 December 1964, p. 6

54. Barata d'água. Published in 08 December 1964, p. 6

55. $O$ veneno das abelhas. Published in 15 December 1964, p. 3

56. Lenda diz que abelhas cantavam hino de natal. Published in 22 December 1964, p. 3

57. Antiguidade da abelha. Published in 29 December 1964, p. 6 
58. Mimetismo. Published in 05 January 1965, p. 3

59. Luz atrai "esperança", que tem cor verde e hábitos noturnos. Published in 12 January 1965, p. 2

60. Mosca parasita de aranha liquida seu hospedeiro. Published in 19 January 1965, p. 6

61. Mosca da madeira: espécime comum nos arredores da capital. Published in 26 January 1965, p. 6

62. Feijão pula para evitar que seu conteúdo morra. Published in 02 February 1965, p. 6

63. "Mutucas" na mitologia grega e na medicina. Published in 09 February 1965, p. 6

64. "Mutucas" na literatura. Published in 16 February 1965, p. 6

65. Praga de coqueiros derruba os frutos. Published in 23 February 1965, p. 6

66. Entomologia nas revistas de divulgação científica. Published in 02 March 1965, p. 8

67. Dos animais da Terra, 70 a $80 \%$ são insetos. Published in 09 March 1965, p. 3

68. A antiguidade do mosquiteiro. Published in 16 March 1965 , p. 3

69. A peste bubônica e a pulga dos ratos. Published in 23 March 1965, p. 2

70. Heróis que desvendaram o mistério da peste. Published in 30 March 1965, p. 6

71. A mosca doméstica só é inofensiva quando morta. Published in 06 April 1965, p. 2

72. Mosca doméstica e mosca de estábulos. Published in 13 April 1965, p. 3

73. Bicho de coco. Published in 27 April 1965, p. 2

74. Aristóteles lançou as bases de uma classificação para os insetos. Published in 04 May 1965, p. 3

75. O microscópio. Published in 11 May 1965, p. 2

76. Bibliófagos. Published in 18 May 1965, p. 3

77. Bibliófagos - II. Published in 25 May 1965, p. 2

78. Insetos nas receitas médicas antigas. Published in 01 June 1965, p. 3

79. Insetos na medicina moderna. Published in 08 June 1965 , p. 2

80. Geleia real. Published in 15 June 1965, p. 7

81. Besouro bombardeiro. Published in 22 June 1965, p. 6

82. Por que os mosquitos sugam sangue. Published in 06 July 1965, p. 3

83. Certas mariposas têm veneno que provoca dermatites. Published in 13 July 1965, p. 3

84. Taturanas que queimam são larvas de mariposa. Published in 20 July 1965, p. 6

85. "Bicho de pé" é a menor pulga que existe. Published in 27 July 1965, p. 3

86. O "general piolho". Published in 03 August 1965, p. 3

87. "Borrachudo". Published in 10 August 1965, p. 3

88. Gigantescos, mas inofensivos. Published in 17 August 1965, p. 6

89. Moscas assassinas. Published in 24 August 1965, p. 2

90. O "canto" do grilo. Published in 31 August 1965, p. 3

91. Amadeu A. Barbiellini. Published in 14 September 1965 , p. 6

92. Na china, grilos foram marechais. Published in 28 September 1965, p. 3

\section{Books (5 titles)}

CARRERA, Messias. Insetos, lendas e história. Brasília: Editora Thesaurus. 1991.

CARRERA, Messias. Anfíbios, Répteis, Aracnídeos, Insetos. São Paulo: Editora Melhoramentos. 1971. [Series Minimagens № 4]

CARRERA, Messias. Aves. São Paulo: Editora Melhoramentos. 1971. [Series Minimagens № 3]

CARRERA, Messias. Mamíferos. São Paulo: Editora Melhoramentos. 1971. [Series Minimagens № 2]

CARRERA, Messias. Moluscos, Crustáceos, Peixes. São Paulo: Editora Melhoramentos. 1971. [Series Minimagens № 5]

\section{Interviews given to daily newspapers (4 titles)}

CARRERA, Messias. Gafanhotos, praga milenar. Folha da Manhã, p. [?]. [?] jun. 1953. [Interview conducted by the journalist Luís Gonzaga Alves]

CARRERA, Messias. Hemipteros, insetos nefastos para os homens e as plantações. Folha da Manhã, p. 6. [?] 1953. [v. XXIX, n. 9033. Interview conducted by the journalist Luís Gonzaga Alves]

CARRERA, Messias. O mundo atravessa a era dos insetos. Folha daManhã, p. 8. [?] 1953. [v. XXIX, n. 8975. Interview conducted by the journalist Luís Gonzaga Alves]

CARRERA, Messias. O mundo das formigas é tão maravilhoso quanto pequeno. Folha da Manhã, p. 11. [?] 1953. [v. XXIX, n. 9051. Interview conducted by the journalist Luís Gonzaga Alves]

\section{Other titles}

A small portion of Carrera's intellectual production, about $20 \%$ (Fig. 10), is not directly related to dipteran taxonomy or science communication. Next, a brief appreciation of these titles will be presented, considering the classification according to the objective (educational material, bibliographical review, necrology and biography, response to letters from readers of Chácaras e Quintais, translation of books, and various topics), as previously presented.

\section{Educational materials}

Among the inventoried titles, seven were clearly structured for educational purposes only and can be considered as didactic material. Of these, five are textbooks prepared for courses taught by the author at the Escola de Higiene e Saúde Pública at USP and the Colégio Anglo-Latino of São Paulo city. Of these, only Carrera (1949b) does not focus on addressing matters relating to insects. Titled Protozoários (Protozoa), this textbook contains 39 pages with information on the morphology, biology, and taxonomy of this group. The simplicity of the language used, and the depth level indicate that Carrera may have used this material 
in his practical Zoology classes at Colégio Anglo-Latino. Another interesting point is that at the end of this textbook, the author uses themes from the sphere of Cultural Entomology to facilitate access to academic knowledge, thus arousing students' curiosity. This device, which can also be found in science communication titles, was used in the textbook entitled Os piolhos - Amenidades para uma aula (Lice - Amenities for a class) (Carrera, 1950).

Among the two books categorized here, Entomologia para você is the author's best known, having seven editions and numerous reprints. Its objective is to disseminate the basic principles of Entomology through simple language, with a reduction in the use of scientific terms and the choice of morphological characters distinguishable by the naked eye. According to Nomura (1958, p. 54), it was "the first popular entomology book, designed to guide the naturalist novel in the vast field of insect classification", having "an important role in awakening dormant vocations". In the introduction to the book, Carrera makes clear his purpose:

If the beginning entomologist feels compelled to compel earlier books on insects, [...], then we will have achieved one of the purposes of our work, which is to encourage the study of Entomology. May the simple teachings of this textbook constitute, today, the initial steps of tomorrow's entomologist. Awakening a vocation is the author's most vehement desire. (Carrera, 1973, p. 11)

\section{List of titles related to Educational Material category}

CARRERA, Messias. Protozoários. São Paulo: Duplicadora Universitária. 1949.

CARRERA, Messias. Insetos da ordem Diptera (Mosquitos e moscas). Cultus, v. 2, n. 7, p. 17-20. 1950.

CARRERA, Messias. Os piolhos - Amenidades para uma aula. Cultus, v. 2, n. 2, p. 1-4. 1950.

CARRERA, Messias. Estudo dos Diptera. Curso Especial de Entomologia Médica. São Paulo: Faculdade de Higiene e Saúde Pública. 1958.

CARRERA, Messias. Generalidades sobre os Dípteros. Curso Especial de Entomologia Médica. São Paulo: Faculdade de Higiene e Saúde Pública. 1958.

CARRERA, Messias. Entomologia para você. São Paulo: EDART. 1973.

CARRERA, Messias. Insetos de interesse médico e veterinário. Curitiba: Editora da UFPR. 1991.

\section{Bibliographic reviews}

As a good book collector, Carrera was very fond of reading. In line, among his titles analyzed, 22 are bibliographic reviews. About half of these titles are in a section of Chácaras e Quintais magazine for this type of publication, called Entre Livros e Folhetos (Between books and leaflets). Of the titles analyzed by him, the vast majority refer to academic and applied Entomology. However, four draw attention because they refer to science communication, they are: $O$ mundo dos artrópodes (The world of arthropods) and Os insetos (The insects), both by Eurico Santos (Santos, 1959, 1961, respectively), Coleópteros do Brasil (Coleoptera of Brazil) by Jacintho Guérin ([?] - [?]) (Guérin, 1953) and Insetos no folclore (Insects in the folklore) by Karol Lenko and Nelson Papavero (Lenko \& Papavero, 1979). The contents of the first two titles most likely served as inspiration for the publication of the column Histórias de insetos, as they were previously published and had characteristics very similar to those of the articles destined to this column.

\section{List of titles referring to the Bibliographic reviews category ( 22 titles)}

CARRERA, Messias. Introdução ao estudo da Drosófila, de N.F. Maia e C. Pavan.Dusenia, v. 1, n. 2, p. 133-134. 1950.

CARRERA, Messias. Die Wanderameisen der Neotropischen Region (Hymenopt. Formicidae). Boletim da Sociedade Brasileira de Entomologia, v. [?], n. [?], p. 5-7. 1955. [Section Livros e Revistas]

CARRERA,Messias. DieWanderameisen der Neotropischen Region (Hymenopt. Formicidae). Ciência e Cultura, v. 7, n. 4, p. 241-242. 1955. [Section Livros e Revistas]

CARRERA, Messias. Coleópteros do Brasil. Boletim da Sociedade Brasileira de Entomologia, v. 1, n. 6, p. 47-48. 1955.

CARRERA, Messias; J. Lane. Neotropical Culicidae, 2 vol. Boletim da Sociedade Brasileira de Entomologia, v. 1, n. 6, p. 46-47. 1955.

CARRERA, Messias; L.P. Travassos Filho e P. Nogueira Neto. A criação de abelhas indígenas sem ferrão. 1953. Boletim da Sociedade Brasileira de Entomologia, v. 1, n. 6, p. 46-47. 1955.

CARRERA, Messias; A. Lutz e N. Tovar. Estudios de Zoologia y Parasitologia Venezolanas. Universidade Central de Venezuela, Caracas, 1928, 137 pp., 26 ests. Boletim da Sociedade Brasileira de Entomologia, v. 1, n. 7, p. 7-8. 1956.

CARRERA, Messias. Culicoides da Região Neotropical (Diptera, Ceratopogonidae). Boletim da Sociedade Brasileira de Entomologia, v. [?], n. [?], p. 25-26. 1956.

CARRERA, Messias. Rev. Pe. Jesus Moure, 1953-5 Hymenoptera - Apoidea, vários títulos. Chácaras e Quintais, v. 93, n. 4, p. 590-591. 1956. [Section Entre Livros e Folhetos]

CARRERA, Messias. "Inseticidas e seu emprêgo no combate às pragas", por Francisco de Assis Menezes Mariconi. Chácaras e Quintais, v. 99, n. 1, p. 91-93. 1959. [Section Entre Livros e Folhetos]

CARRERA, Messias. "O Caminho da Sobrevivência", de William Vogt. Chácaras e Quintais, v. 99, n. 2, p. 207-208. 1959. [Section Entre Livros e Folhetos]

CARRERA, Messias. "Problemas Entomológicos do Cacaueiro com Referência à Bahia", de Pedrito Silva. Chácaras e Quintais, v. 100, n. 2, p. 415-416. 1959. [Section Entre Livros e Folhetos] 
CARRERA, Messias. Culicoides da Região Neotropical, por Oswaldo P. Forattini. Chácaras e Quintais, v. 99, n. 1, p. 93. 1959. [Section Entre Livros e Folhetos]

CARRERA, Messias. "Em defesa do livro", uma obra que ensina como acabar com os insetos que destroem bibliotecas. Chácaras e Quintais, v. 101, n. 4, p. 378. 1960. [Section Entre Livros e Folhetos]

CARRERA, Messias. "O mundo dos artrópodes", mais um belo livro de Eurico Santos. Chácaras e Quintais, v. 101, n. 4, p. 377. 1960. [Section Entre Livros e Folhetos]

CARRERA, Messias. Medical Entomology, W.B. Herms \& M.T. James. Chácaras e Quintais, v. 104, n. 3, p. 488-489. 1961. [Section Entre Livros e Folhetos]

CARRERA, Messias. Os insetos, de Eurico Santos, vol. I Entre Livros e Folhetos. Chácaras e Quintais, v. 105, n. 4, p. 462. 1962. [Section Entre Livros e Folhetos]

CARRERA, Messias. "Catálogo dos Mirídeos do Mundo", parte V, vol. 51 dos Arquivos do Museu Nacional, 194 pp., 1960, de José Cândido M. Carvalho. Chácaras e Quintais, v. 107, n. 4, p. 402-403. 1963. [Section Entre Livros e Folhetos]

CARRERA, Messias. The Tabanidae of Florida, de Calvin M. Jones \& Darrel W. Aniphony, 1964. Chácaras e Quintais, v. 111, n. 5, p. 411-412. 1965. [Section Entre Livros e Folhetos]

CARRERA, Messias. Insetos no folclore. Revista Brasileira de Entomologia, v. 24, n. 1, p. 71-72. 1980.

CARRERA, Messias. História viva de Museu - Les jardiniers du roy (petite histoire du jardin des plantes de Paris, por Guy Barthélemy, 1979, 296 pp., 82 figs.). Ciência e Cultura, v. 34, n. 9, p. 1264-1269. 1982.

CARRERA, Messias. Les Jardiniers du Roy (Petite histoire du jardin des plantes de Paris). Revista Brasileira de Entomologia, v. 27, n. 2, p. 189-190. 1983.

\section{Obituaries and biographies}

About biographical works, six titles of the author were considered, dealing with four researchers, namely: Amadeu Amadei Barbiellini; Ladislau Martin Aczél (1906-1958), Hungarian botanist who at the end of his career dedicated himself to the study of dipterans (Carrera, 1962b); Pierre André Latreille (1762-1833), famous French entomologist (Carrera, 1958a); and Renato de Roberto Corrêa. Three of these titles (Carrera, 1958a, b, 1962a), published in different journals, deal with the famous researcher Pierre André Latreille. The content present in these three titles is basically the same. It is evident that Carrera (1962a) is, in fact, a transcription of Carrera (1958b), due to the then bicentenary of Latreille's birth.

\section{List of titles related to the obituary and biographies category ( 6 titles)}

CARRERA, Messias. Necrológio - Conde Amadeu A. Barbiellini. Revista Brasileira de Entomologia, v. 4, p. 213-216. 1956.
CARRERA, Messias. Latreille, um Entomólogo desafortunado. Chácaras e Quintais, v. 98, n. 1, p. 90. 1958.

CARRERA, Messias. Pierre-André Latreille. Boletim da Sociedade Brasileira de Entomologia, v. 1, n. 9, p. 3-18. 1958.

CARRERA, Messias. Ladislau Martin Aczél (1906-1958). Studia Entomologica, v. 5, n. 1-4, p. 579-581. 1962.

CARRERA, Messias. Pierre André Latreille (1762-1833). Studia Entomologica, v. 5, n. 1-4, p. 571-579. 1962.

CARRERA, Messias. Necrológio - Renato de Roberto Corrêa. Revista Brasileira de Entomologia, v. 31, n. 3, p. 480.1987.

\section{Responses to letters from readers of Chácaras e Quintais magazine}

In the 1950s, the magazine Chácaras e Quintais was a reference for educational activities related to the rural environment (Antuniassi \& Moura, 2005). Many readers sent letters with questions on various related subjects. Some of them, which slipped in some way to Entomology, were answered by Carrera, especially in the section No mundo dos insetos. According to Carrera (1991b), ten queries on entomology were answered. However, when analyzing the numbers of this magazine, these responses' authorship proved to be difficult to identify. Another doubt is that some responses have become so extensive that they have taken an article's structure. Thus, these were considered in this work as science communication titles and not as simple responses to readers. For these reasons, only eight responses were considered. Among these, several subjects related to Entomology were dealt with. As an example, on May 15, 1959, the author replies to Mr. Pascoalino Bernardi, explaining the creation and trade of butterflies (Carrera, 1959). In another, published on April 15, 1960, he talks about insects' conservation for collection purposes to answer a question sent by the reader identified as Mr. M.M. de Cachoeiro de Itapemirim, ES (Carrera, 1960a). As the last example, we can highlight a question that is not very "entomological". In this, the reader identified as Orivaldo Albuquerque from the city of Correntes, PE, would like to know how to acquire the book Lepidópteros do Brasil (Lepidoptera of Brazil) (Silva, 1907) by Benedito Raymundo da Silva ([?]-[?]). He presented this interest from the cover of the first edition of the book Entomologia para você, which has an illustration taken from that book (Carrera, 1960b).

\section{List of titles related to the Responses to Letters category (8 titles)}

CARRERA, Messias. Comércio de borboletas. Chácaras e Quintais, v. 99, n. 5, p. 595-596. 1959. [Section No mundo dos insetos]

CARRERA, Messias. Colecionando insetos. Chácaras e Quintais, v. 101, n. 4, p. 423. 1960. [Section No mundo dos insetos] 
CARRERA, Messias. Uma obra de Benedito Raymundo. Chácaras e Quintais, v. 102, n. 3, p. 536. 1960.

CARRERA, Messias. Abelhas cortando folhas. Chácaras e Quintais, v. 102, n. 6, p. 943-944. 1960.

CARRERA, Messias. Besouro que suga sangue. Chácaras e Quintais, v. 102, n. 6, p. 943. 1960. [Section No mundo dos insetos]

CARRERA, Messias. Bicho geográfico das praias. Chácaras e Quintais, v. 102, n. 6, p. 944. 1960.

CARRERA, Messias. Colecionando insetos. Chácaras e Quintais, v. 102, n. 6, p. 944. 1960.

CARRERA, Messias. Dificuldades na classificação de insetos. Chácaras e Quintais, v. 107, n. 1, p. 24. 1963.

\section{Book translations}

Carrera also participated in the translation of books for science communication and curiosities. In this article, nine titles were inventoried and in Nomura (1995a, b). Carrera (1991b) mentions the existence of ten translations. Of the titles considered here, seven refer to science communication in Zoology, with only one regarding insects. The two others have nothing to do with zoology, dealing with curiosities in the area of aeronautics and nautics.

\section{List of titles referring to the book translation category ( 9 titles)}

FOSSETTI, G[?]. Enciclopédia dos Animais. São Paulo: Edições Melhoramentos. 1969.

BIRAN, G[?] B. Gatos. São Paulo: Edições Melhoramentos. 1972. [Series Mini Universo, № 4]

FICHTER, George F. Cobras. São Paulo: Edições Melhoramentos. 1972. [Series Mini Universo, № 6]

FICHTER, George S. Insetos. São Paulo: Edições Melhoramentos. 1972. [Series Mini Universo, № 3]

HATHWAY, James A. Aviões e pilotos famosos. São Paulo: Edições Melhoramentos. 1972. [Series Mini Universo, № 8]

STEVENSON, George B. Aves. São Paulo: Edições Melhoramentos. 1972. [Series Mini Universo, № 2]

STEVENSON, George B. Mamíferos. São Paulo: Edições Melhoramentos. 1972. [Series Mini Universo, № 1]

STEVENSON, George B. Navios. São Paulo: Edições Melhoramentos. 1972. [Series Mini Universo, № 9]

MONEY, Sali. Reino Animal. São Paulo: Edições Melhoramentos. 1977. [Series Prisma, o conhecimento em cores]

\section{Various themes}

In this category, seven titles were grouped. Among these, five are notices to the definition of zoology terms present in dictionaries. The zoological groups addressed are diverse, with insects being the most focused, with two titles, and others for mollusks and birds. Two other titles were published in the Noticiário (News) section of Revista Brasileira de Entomologia. One is Carrera's speech at the time of receiving the José Reis Award, modality for Science Communication, from 1988. The author briefly addresses the history of science communication in Brazil (Carrera, 1989). The other, very interesting by the way, is entitled $A$ sistemática dos sistematas (The systematic of systematists) (Carrera, 1982). In this, a part of Stritt (1952) is transcribed, where a dichotomous key is presented, in which the systematic entomologists are characterized, treating them as subspecies of Entomologus systematicus. Carrera includes a new subspecies, Entomologus systematicus ciberneticus, which can be understood as a direct criticism of numerical taxonomy. He describes this subspecies as:

"Entomologist who loves numerical taxonomy; idealizes a "system" of data applied to insects; uses the calculation of probabilities and the theory of functions; argues with statistics on similarity coefficients, connection graphs, and other transcendent criteria". (Carrera, 1982, p. 212)

\section{List of titles referring to the category Various themes ( 7 titles)}

CARRERA, Messias. A sistemática dos sistematas. Revista Brasileira de Entomologia, v. 26, n. 2, p. 211-212. 1982.

CARRERA, Messias. Discurso de Messias Carrera para o Prêmio José Reis. Revista Brasileira de Entomologia, v. 33, n. 1, p. 157-159. 1989.

CARRERA, Messias. Reparos à zoologia dos dicionários I. Insetos. Revista Brasileira de Entomologia, v. 35, n. 2, p. 469-483. 1991.

CARRERA, Messias. Reparos à zoologia dos dicionários - Moluscos. In: X Encontro Brasileiro de Malacologia, v. 105, p. 12-14. 1991.

CARRERA, Messias. Reparos à zoologia dos dicionários. Insetos II. Revista Brasileira de Entomologia, v. 36, n. 3, p. 703-706. 1992.

CARRERA, Messias. Reparos à zoologia dos dicionários. III. Aves. Revista Brasileira de Zoologia, v. 10, n. 2, p. 367-370. 1993.

CARRERA, Messias. Reparos à zoologia dos dicionários. IV. Revista Brasileira de Biologia, v. 10, n. 3, p. 531-534. 1993.

\section{General discussion}

From the historical and anthropological point of view, human intellectual production can be divided into three domains: scientific, technological, and humanistic. The scientific domain would be related to the generation of pure knowledge. In contrast, the technological domain would be relevant to the applicability of the knowledge produced by science. In the humanities domain, there are the intellectual activities that human beings practice 
for "the food of the mind and soul" (Hogue, 1980, p. 33), that is, the so-called "sciences", based on empiricism and sensory experiences, such as philosophy, languages, music, arts, interpretive history, theology. This last set would be responsible, more than the first two, for characterizing human cultural groups (Hogue, 1980). Applying this view in Entomology, it can be subdivided into Academic Entomology, Economic Entomology, and Cultural Entomology. The latter was defined by Hogue (1987) as the branch of investigation that addresses the influence of insects and other terrestrial arthropods in activities related to the sphere of the humanities, that is, it would be the study of the impressions caused by these animals in the most varied human cultural groups.

From the data collected and presented in the present study, it can be inferred that Carrera's academic production proved to be quite expressive and significant for the taxonomy of insects of the order Diptera. His efforts in organizing and structuring the collection of this group, which today is under the responsibility of MZUSP, enabled the development of dipterology in the State of São Paulo. From a small box of insects found in the Museu Paulista collection, he built what can now be considered the largest collection of dipterans in Brazil, comprising about one million pieces (verbal information ${ }^{6}$ ). Considering the relationship between the number of taxa initially proposed and those with valid taxonomic status after a few decades, the author's effective productivity is in the order of $84.4 \%$. Considering that, in the last survey, about 220 genera and 1,600 species for the Asilidae family are listed in the Neotropical Region (Papavero, 2009; Carvalho et al., 2012), the author would be responsible for $6 \%$ of the genera and $5.4 \%$ of the species. Given the data previously presented, it can be inferred that his contribution to the order's taxonomy was important, especially for the Asilidae family.

However, he did not stick to Academic Entomology, he was also concerned with the applicability of entomological knowledge to the economic environment. This fact can be reinforced by having as an example two of his titles: the book entitled Insetos de interesse médico e veterinário (Carrera, 1991a) and some of his articles, such as História dos insetos inimigos dos livros (History of insects that are book enemies) (Carrera, 1981). Like these, other titles by the author deal with Entomology in a more technical and applied way and certainly were important for the practice of professionals in the relative areas.

Science communication in Brazil developed since the late 1940s, when the country was undergoing important political changes, with the end of Estado Novo and the consequent resumption of democracy. According to Esteves (2011, p. 14), the political context generated "[...] a fertile space for scientific dissemination in newspapers in Rio de Janeiro and São Paulo [...]". Thus, several initiatives appear in newspapers in these cities, especially between the 1940s and 1960s. The columns No mundo da ciência (In the world of science) and Ciência dia a dia (Science of daily living), both signed by José Reis

6 Information provided by Prof. Dr. Nelson Papavero when interviewed. and published, respectively, in the newspapers Folha da Manhã and Folha da Noite (Esteves, 2011), can be cited as examples. Most of Carrera's scientific outreach titles, such as the Histórias de insetos column, were produced just at that time, certainly under the influence of these and other initiatives, and of the political events of the late 1940s. Thus, their titles can be considered as part of the first efforts to bring scientific knowledge to the lay public.

The author's commitment to the dissemination of scientific knowledge is evident, but in the interviews carried out and in the other research sources consulted, the reason for this effort was not well understood. However, besides the political issues of the time, it can be assumed that he brings his experience as a Basic Education teacher. The students' lack of interest in the life of insects, who lived in the big city, should be clear, which, in a way, frustrated him. Another possibility may be related to the large circulation at the time of popular knowledge based on folklore since the State of São Paulo received many workers from other regions of Brazil (Fazenda, 1988). This type of knowledge was certainly very rich in this scenario, but not necessarily corresponding to the scientific one. Regardless of the reason, the author understood the importance of scientific information for the lay public. In the preamble of his book Insects, legends, and history, he makes it clear that "[...] it has no other purpose than to arouse curiosity, disseminating useful knowledge about the life of insects [...]" (Carrera, 1991b, p. 11).

Considering the professional experience, as a teacher, and his production related to education, it is evident that Carrera also contributed, albeit in a simple way, to the Teaching area, especially related to Zoology. In the 1950s, when the author acted as a teacher, the main educational movement in force in Brazil was the so-called Escola Nova (New School). Such a movement, rooted in the ideas of Piaget's constructivism, saw the school as one of the instruments for creating a united and fraternal society. In this way, it would present better results than those obtained by the traditional school (Vasconcelos, 1996). The ideals of this educational movement may have influenced the practice as an educator and the author's bibliographic production related to Teaching. During that period, the use and production of textbooks were very incipient, and the few that were used were translations of foreign books (e.g., Freitag et al., 1989). Thus, titles of this kind, such as the book Entomologia para você, were of great importance for education in Brazil, especially for students who wanted to take courses related to biological areas.

Analyzing the general panorama of Carrera's intellectual production, it can be highlighted that at the beginning of his career, at the beginning of the 1940s, he dedicated himself more to the scientific sphere. However, his science communication production quickly gained importance, surpassing scientific production between the 1950s and 1960s. During the 1970s there was a very sharp decrease in the number of titles published in general (Fig. 11). This fact may be related to his retirement, which occurred in the early 1960s, and, mainly, to his health issues since it was precisely in the 1970s that he was diagnosed with 
cancer. His production resumed in the 1980s, but exclusively with titles related to science communication.

Given all the information raised, it is concluded that Carrera was an entomologist who was ahead of his time. In addition to covering and, in a certain way, his intellectual production, positively impacting the three spheres of knowledge, presents important advances for the areas in which the author acted.

\section{ACKNOWLEDGEMENTS}

We are very grateful to everyone who took the time to contribute to this research. We are very grateful to Mrs. Helena Carrera Chiavassa and her husband, Mr. Sérgio Chiavassa, for the very pleasant reception at their residence, for the availability of materials (photos and prizes) and information regarding the life of Messias Carrera. To professors Dr. Nelson Papavero and Hitoshi Nomura (in memorian) for their immense patience in providing information, materials (articles and books), and answering questions. To the other USP professors and employees for their interviews. To Maristela Chiarastello Farinha and Sonia Favaro de Araújo, employees of the personnel and expedient section at the Museu de Zoologia of USP (MZUSP), for recovering and making available the functional portfolio of the studied author, and to Prof. Dr. Marcos Domingos Siqueira Tavares, director of MZUSP (2014 2018), for authorizing the use of the information and photographs present there. This study was financed in part by the Coordenação de Aperfeiçoamento de Pessoal de Nível Superior - Brasil (CAPES) - Finance Code 001 and C.J.E.L. received financial support from Conselho Nacional de Desenvolvimento Científico e Tecnológico - CNPq (Proc. № 302751/2019-0).

This paper is part of the doctoral thesis of the first author, defended in July 2018 in the Programa de Pós-Graduação em Zoologia of the Museu Nacional, Universidade Federal do Rio de Janeiro.

\section{REFERENCES}

Agricultura. 1998. Falecimento: Júlio Seabra Inglez de Souza (1915-1998). Revista de Agricultura, 73(3): 314.

Anonymous. 1984. Cinquientenário da Criação da Universidade de São Paulo. Revista de Saúde Pública, São Paulo, 18(6): 522. Available: http://doi. org/10.1590/S0034-89101984000600013. Access: 09/07/2020.

Antuniassi, M.H.R. \& Moura, M.I.G.L. 2005. A Revista Chácaras e Quintais e a comunicação rural. Cadernos (ERU, 2(16): 183-192. Available: https:// www.revistas.usp.br/ceru/article/view/75351. Access: 29/08/2017.

Artigas, J.N. \& Angulo, A. 0. 1980. Revisión del género Mallophora Macquart por sistemática alfa y numérica (Diptera - Asilidae). Gayana Zoologia, 43: 1-182.

Artigas, J.N. \& Papavero, N. 1988. The american genera of Asilidae (Diptera): Keys for identification with an atlas of female spermathecae and other morphological details. II. Key to the genera of Dasypogoninae Macquart, with descriptions of new genera and species and new synonymies. Gayana Zoologia, 52(3-4): 199-260.

Artigas, J.N.; Papavero, N. \& Pimentel, T. 1988. The American genera of Asilidae (Diptera): Keys for identification with an atlas of female spermathecae and other morphological details. IV. Key to the genera of Laphriinae
Macquart (except tribe Atomosiini Hermann), with the descriptions of three new tribes and five new species. Boletim do Museu Paraense Emílio Goeldi, serie Zoologia, 4(2): 211-256.

Brasil. 1953. Despachos proferidos pelo governador. Diário Oficial do Estado de São Paulo, Diário do Executivo - Governo do Estado, 63(265): 1-2.

Campello, B.S.; Andrade, M.E.A. \& Medeiros, N.L. 1993. Enciclopédias publicadas no Brasil: estudo comparativo das enciclopédias Mirador, Barsa e Delta Universal. Ciência da Informação, 22(1): 44-52.

Carrera, M. 1939. Moscas assassinas. Chácaras e Quintais, 60(5): 620-623.

Carrera, M. 1940. Novas espécies do gênero Rachicerus Walk, 1854 (Dipt). Arquivos de Zoologia do Estado de São Paulo, 1(13): 387-398.

Carrera, M. 1949a. Contribuição ao conhecimento dos Asilidae neotropicais (Diptera) - I - Sobre as espécies brasileiras com esporão na tíbia. Arquivos de Zoologia do Estado de São Paulo, 7(1): 1-148.

Carrera, M. 1949b. Protozoários. São Paulo, Duplicadora Universitária.

Carrera, M. 1950. Os piolhos - Amenidades para uma aula. Cultus, São Paulo, 2(2): 1-4.

Carrera, M. 1956. Necrológio do Conde Amadeu A. Barbiellini. Revista Brasileira de Entomologia, 4: 213-216.

Carrera, M. 1958a. Latreille, um Entomólogo desafortunado. Chácaras e Quintais, 98(1): 90.

Carrera, M. 1958b. Pierre-André Latreille. Boletim da Sociedade Brasileira de Entomologia, 1(9): 3-18.

Carrera, M. 1959. Comércio de borboletas. Chácaras e Quintais, 99(5):595-596. [Section No mundo dos insetos]

Carrera, M. 1960a. Colecionando insetos. Chácaras e Quintais, 101(4): 423. [Section No mundo dos insetos]

Carrera, M. 1960b. Uma obra de Benedito Raymundo. Chácaras e Quintais, 102(3): 536

Carrera, M. 1962a. Pierre André Latreille (1762-1833). Studia Entomologica, 5(1-4): 571-579.

Carrera, M. 1962b. Ladislau Martin Aczél (1906-1958). Studia Entomologica, 5(1-4): 579-581.

Carrera, M. 1964. Dicionários e insetos nem sempre estão de acordo. Folha de S. Paulo. Section Folha llustrada, column Histórias de insetos, p. 3. 08 Sep. [v. XLIV, n. 12868]

Carrera, M. 1973. Entomologia para você. São Paulo, EDART.

Carrera, M. 1981. História dos insetos inimigos dos livros. Ciência e Cultura, 33(3): 353-361.

Carrera, M. 1982. A sistemática dos sistematas. Revista Brasileira de Entomologia, 26(2): 211-212.

Carrera, M. 1987. Necrológio - Renato de Roberto Corrêa. Revista Brasileira de Entomologia, 31(3): 480.

Carrera, M. 1989. Discurso de Messias Carrera para o Prémio José Reis. Revista Brasileira de Entomologia, 33(1): 157-159.

Carrera, M. 1991a. Insetos de interesse médico e veterinário. Curitiba, Editora da UFPR.

Carrera, M. 1991b. Insetos, lendas e história. Brasília, Editora Thesaurus.

Carrera, M. 1991c. Reparos à zoologia dos dicionários. I. Insetos. Revista Brasileira de Entomologia, 35(2): 469-483.

Carrera, M. 1991d. Reparos à zoologia dos dicionários. Moluscos. Boletim Informativo da Sociedade Brasileira de Malacologia, 105: 11-14.

Carrera, M. 1992. Reparos à zoologia dos dicionários. II. Insetos. Revista Brasileira de Entomologia, 36(3): 703-706.

Carrera, M. 1993a. Reparos à zoologia dos dicionários. III. Aves. Revista Brasileira de Zoologia, 10(2): 367-370.

Carrera, M. 1993b. Reparos à zoologia dos dicionários. IV. Revista Brasileira de Biologia, 10(3): 531-534.

Carrera, M. 1995a. Escarabeoideos Fúnebres e Sagrados. Revista Brasileira de Entomologia, 39(2): 475-477. 
Carrera, M. 1995b. 0 "besouro bombardeiro" e seu aparelho detonante. Revista Brasileira de Entomologia, 39(2): 479-481.

Carrera, M. \& Papavero, N. 1962. Saropogonini neotropicais (Diptera, Asilidae, Dasypogoninae). Studia Entomologica, 5(1-4): 39-64.

Carvalho, C.J.B.; Couri, M.S.; Toma, R.; Rafael, J.A.; Harada, A.Y.; Bonatto, S.R.; Henriques, A.L. \& Gastal, H.A.0. 2002. Principais coleções brasileiras de Diptera: histórico e situação atual. In: Costa, C.; Vanin, S.A.; Lobo, J.M. \& Melic, A. Proyecto de Red Iberoamericana de Biogeografía y Entomología Sistemática PrIBES 2002. Zaragoza, SEA \& CYTED. p. 37-52.

Carvalho, C.J.B.; Rafael, J.A.; Couri, M.S. \& Silva, V.C. 2012. Diptera. In: Rafael, J.A.; Melo, G.A.R.; Carvalho, C.J.B; Casari, S.A. \& Constantino, R. Insetos do Brasil. Diversidade e Taxonomia. Ribeirão Preto, Editora Holos. p. 701-743.

Conselho Nacional de Desenvolvimento Científico e Tecnológico (CNPq). 2010. XXX Edições do Prêmio José Reis, Divulgação Científica e Tecnológica. Brasília, Ministério da Ciência e Tecnologia.

Correio Paulistano. 1934. Festival poly-esportivo em benefício da cruzada Pró Infância. Correio Paulistano, p. 19[?]. 21 0ct.

Correio Paulistano. 1935a. Pelo clube de regatas Tietê. Correio Paulistano, p. 7. 25 Apr. [v. LXXXI, n. 24259]

Correio Paulistano. 1935b. Correios e Telégrafos. Correio Paulistano, p. 4. 28 Sep. [v. LXXXII, n. 24393]

Couto, R.C. 2011. Juscelino Kubitschek. Brasília, Câmara dos Deputados, Edições Câmara, Senado Federal, Edições Técnicas.

Crozariol, M.A. 2017. Necrológio: Hitoshi Nomura (1933-2017). Atualidades Ornitológicas, 200: 28-29.

Dias, C.E.S.B. 2013. Notas biográficas. Cadernos de História da Ciência, 9: $172-180$.

Donato, H. 2002. História da Revolução Constitucionalista de 1932: comenorando os 70 anos do evento. São Paulo, IBRASA.

Esteves, B. 2011. Os cientistas vão à imprensa: divulgação científica nos jornais brasileiros (1945-1964). In: Massarani, L.; Jurberg, C. \& Meis, L. de. Um gesto ameno para acordar o país. A ciência no Jornal do Commercio [1958-1962]. Rio de Janeiro, Fundação Oswaldo Cruz, Casa de Oswaldo Cruz e Museu da Vida, p. 13-23.

Fazenda, I.C.A. 1988. Educação no Brasil Anos 60: 0 pacto do silêncio. São Paulo: Edições Loyola. [Collection Educar 2].

Folha de S. Paulo. 1944. Colégio Anglo-Latino. Folha da Manhã, p. 6. [v. XIX, n. 6106, Propaganda do Colégio Anglo-Latino]

Fonseca, E.N. 1972. 0 Negócio das Enciclopédias. Ciência da Informação, 1(2): 91-98.

Freitag, B.; Motta, V.R. \& da Costa, W.F. 1989. 0 livro didático em questão. São Paulo, Cortez Editora.

Galileo, M.H.M. \& Santos-Silva, A. 2015. Necrológio Ubirajara Ribeiro Martins de Souza (1932-2015). Arquivos de Zoologia Museu de Zoologia da Universidade de São Paulo, 46(2): 41-64.

Giacheti, L.J.M. 2006. José Reis - A ciência que fala. São Paulo: Annablume, FAPESP.

Guérin, J. 1953. Coleópteros do Brasil. São Paulo, Faculdade de Filosofia, Ciências e Letras da Universidade de São Paulo, Departamentos de Zoologia e de Fisiologia Geral e Animal.

Guimarães, J.H. \& Papavero, N. 1999. Myiasis in man and animals in the Neotropical Region. Bibliographic database. São Paulo, Fundação de Amparo à Pesquisa do Estado de São Paulo \& Editora Plêiade.

Höfling, E. 2006. Obituário Hélio Ferraz de Almeida Camargo. Revista Brasileira de Ornitologia, 14(3): 301-302.

Hogue, C.L. 1980. Commentaries in Cultural Entomology I. Definition of cultural entomology. Entomological News, 91(2): 33-36.

Hogue, C.L. 1987. Cultural Entomology. Annual Reviews of Entomology, 32: 181-199.
Kaphan, E.M.S. 2003. Paulo Sawaya (1903-2003). Jornal da USP, 18(657): [s.p.]. Available: http://www.usp.br/jorusp/arquivo/2003/jusp657/ pag02.htm. Access: 28/08/2017.

Klassa, B. \& Santos, C.M. 2014. The man who loved flies: a biographical profile of Nelson Papavero. Zootaxa, 3793(2): 201-221. Available: http://doi. org/10.11646/zootaxa.3793.2.1. Access: 28/08/2017.

Lamas, C.J.E.; Nihei, S.S. \& Papavero, N. 2008. Necrológio - José Henrique Guimarães (08/10/1937-14/10/2008). Revista Brasileira de Entomologia, 52(4): 674-676.

Lenko, K. \& Papavero, N. 1979. Insetos no folclore. São Paulo, Conselho Estadual de Artes e Ciências Humanas. (Coleção Folclore n. 18).

Martin, C.H. 1975. Review of the genus Schildia Aldrich (Diptera: Leptogastridae). Proceedings of the Entomological Society of Washington, 77: 189-193.

Mayer, J.M. \& Garcez, L.N. [s.d.]. Available: http://www.fgv.br/cpdoc/ acervo/dicionarios/verbete-biografico/garcez-lucas-nogueira. Access: 28/08/2017.

Mendes, E.G. 1994. Ernest Marcus. Estudos Avançados, 8(22): 209-213.

Moreira, I.C. \& Massarani, L. 2002. Aspectos históricos da divulgação científica no Brasil. In: Massarani, L; Moreira, I.C. \& Brito, F. Ciência e público: caminhos da divulgação científica no Brasil. Rio de Janeiro, UFRJ, p. 43-64.

Nomura, H. 1958. Livro popular sobre insetos. Fauna: Órgão Oficial Mensal do Caçador e Pescador Nacional, 16(1): 54-56.

Nomura, H. 1991a. Olivério Pinto (1896-1981). In: Nomura, H. Vultos da Zoologia Brasileira, Volume I. Mossoró, Escola Superior de Agricultura de Mossoró, Fundação Guimarães Duque, p. 112-117. (Coleção Mossoroense, Series "C", Volume DCLXI)

Nomura, H. 1991b. Frederico Lane (1901-1979). In: Nomura, H. Vultos da Zoologia Brasileira, Volume II. Mossoró: Escola Superior de Agricultura de Mossoró, Fundação Guimarães Duque, p. 140-142. (Coleção Mossoroense, Series "C", Volume DCLXII)

Nomura, H. 1991c. John Lane (1905-1963). In: Nomura, H. Vultos da Zoologia Brasileira, Volume ll. Mossoró, Escola Superior de Agricultura de Mossoró, Fundação Guimarães Duque, p. 155-157. (Coleção Mossoroense, Series " $C$ ", Volume DCLXII)

Nomura, H. 1992. Lauro Travassos Filho (1918-1989). In: Nomura, H. Vultos da Zoologia Brasileira, Volume V. Mossoró, Escola Superior de Agricultura de Mossoró, Fundação Guimarães Duque, p. 242-244. (Coleção Mossoroense, Series "C", Volume 772)

Nomura, H. 1995a. Necrológio - Messias Carrera. Revista Brasileira de Entomologia, 39(1): 229-235.

Nomura, H. 1995b. Messias Carrera. In: Nomura, H. Vultos da Zoologia Brasileira, Volume VI. Mossoró, Fundação Vingt-um Rosado, ETFRNUNED de Mossoró, Secretaria de Agricultura e Abastecimento de RN, p. 103-105. (Coleção Mossoroense, Series " $C$ ", Volume 861).

Oliveira, S.J. 1989. A vida profissional de Hugo de Souza Lopes. Memórias do Instituto Oswaldo Cruz, 84: 3-4.

Palma Filho, J.C. 2010. A educação brasileira no período de 1930 a 1960: a Era Vargas. In: Universidade Estadual Paulista, Caderno de Formação de professores: Formação de professores-educação, cultura e desenvolvimento. São Paulo, Cultura Acadêmica. p. 85-103.

Papavero, N. 1971. Notes on some types of Neotropical Asilidae (Diptera), with descriptions of three new species. Papéis avulsos de Zoologia, São Paulo, 25(3): 19-29.

Papavero, N. 1975. Studies of Asilidae (Diptera) systematics and evolution. IV. Tribe Megapodini Carrera (Dasypogoninae), with a review of the Neotropical species. Arquivos de Zoologia do Estado de São Paulo, 26(3): 191-318.

Papavero, N. 2009. Catalogue of Neotropical Diptera. Asilidae. Ribeirão Preto, Departamento de Biologia, FFCLRP/USP. 178p. (Neotropical Diptera, 17). 
Papavero, N. \& Bernardi, N. 1973. Studies of Asilidae (Diptera) systematics and evolution. III. Tribe Blepharepiini (Dasypogoninae). Arquivos de Zoologia do Estado de São Paulo, 24(3): 163-209.

Pape, T. \& Thompson, F.C. 2013. Systema Dipterorum, Version 1.5. Available: http://www.diptera.org. Access: 28/08/2017.

Pujol-Luz, J.R. 2019. A new species of the genus Rachicerus Walker (Diptera: Xylophagidae), with notes on Messias (arrera's 1940 and 1945 types housed in Museu de Zoologia, Universidade de São Paulo and Instituto Oswaldo Cruz, Rio de Janeiro, Brazil. Zootaxa, 4668(1): 126-134.

Rafael, J.A. 2017. Diptera In: Catálogo Taxonômico da Fauna do Brasil. PNUD. Available: http://fauna.jbrj.gov.br/fauna/faunadobrasil/252. Access: 28/08/2017.

Rocha, A.A. 1992. A poluição do rio Tietê: a consequiência de um sectário, processo político. São Paulo em Perspectiva, 6(1-2): 93-98.

Santos, E. 1959. 0 mundo dos artrópodes. Rio de Janeiro: Editora F. Briguiet \& Cia.

Santos, E. 1961. Os insetos: vida e costumes, Volume 1. Rio de Janeiro, Editora F. Briguiet \& Cia. 206p.
Schmitt, M. 2010. Willi Hennig, the cautious revolutioniser. Palaeodiversity, 3(Supplement): 3-9.

Silva, B.R. 1907. Lepidópteros do Brasil: contribuição para a História Natural. Rio de Janeiro,: BR Imprensa Nacional.

Straube, F.C. 2009. Uma visão bio-bibliográfica de Eurico Santos: divulgador da natureza brasileira. Atualidades Ornitológicas On-line, 148: 38-45. Available: www.ao.com.br/download/a0148 38.pdf. Access: 28/08/2017.

Stritt, W. 1952. Zur Systematik der Systematiker, insbesondere der entomologischen (Hom. Ent.), nebst einer Bestimmungstabelle. Entomologische Zeitschrift, 62(7): 49-53. apud Carrera, M. 1982. A sistemática dos sistematas. Revista Brasileira de Entomologia, 26(2): 211-212.

Thompson, F.C.; Vockeroth, J.R. \& Sedman, Y.S. 1976. Family Syrphidae. 46. In: A catalogue of the Diptera of the Americas south of the United States. São Paulo, Departamento de Zoologia da Secretaria da Agricultura.195p. Vasconcelos, M.S. 1996. A difusão das idéias de Piaget no Brasil. São Paulo, Casa do Psicólogo. 